\title{
DEVELOPMENT OF OVARIAN GERMLINE STEM CELLS IN NILE TILAPIA (Oreochromis niloticus) REARED UNDER DIFFERENT TEMPERATURE REGIMES
}

\author{
Dissertation \\ Submitted to obtain the PhD Degree \\ at the Faculty of Agricultural Sciences \\ Georg-August-University Göttingen, Germany
}

Presented by

Aulidya Nurul Habibah

from Banyumas, Indonesia

Göttingen, July 2016 


\section{D7}

1. Supervisor: Prof. Dr. Gabriele Hoerstgen-Schwark

2. Co-supervisor: Prof. Dr. Wolfgang Holtz, PhD

Date of disputation: July $5^{\text {th }}, 2016$ 


\section{Table of Contents}

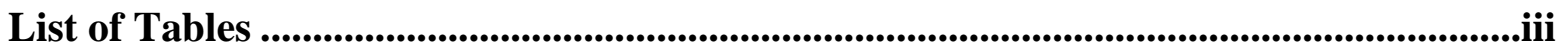

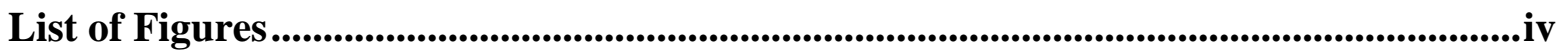

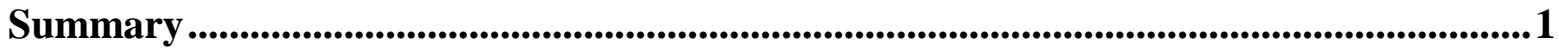

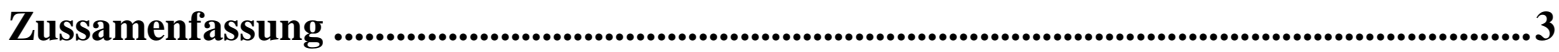

CHAPTER 1 INTRODUCTION TO SEXUAL DEVELOPMENT OF NILE TILAPIA (Oreochromis niloticus)...........................................................................5

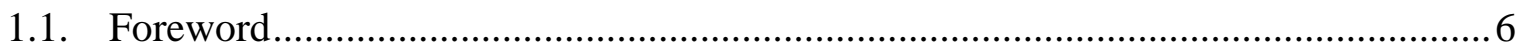

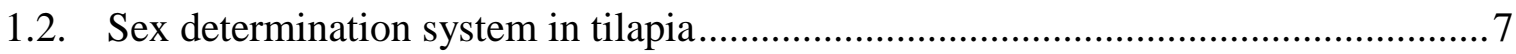

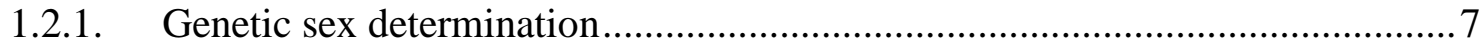

1.2.2. Temperature-dependent sex determination ................................................... 8

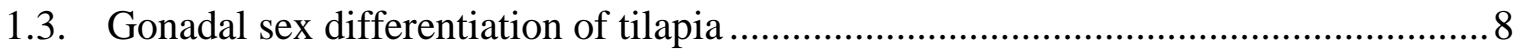

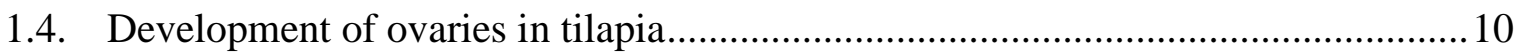

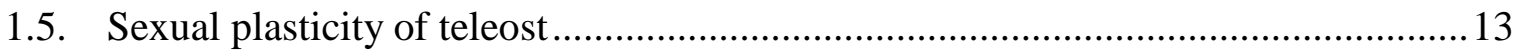

1.6. Germline stem cell renewal in teleost................................................................. 14

1.7. Endocrine and molecular control of sex differentiation of tilapia.......................... 15

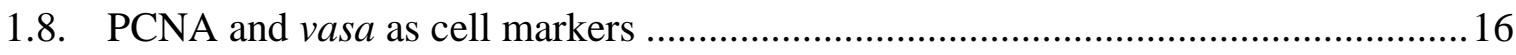

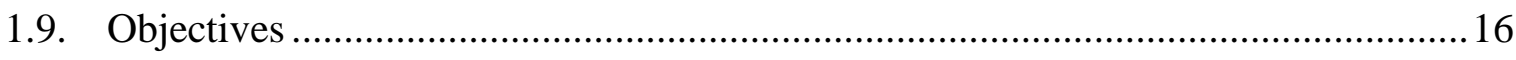

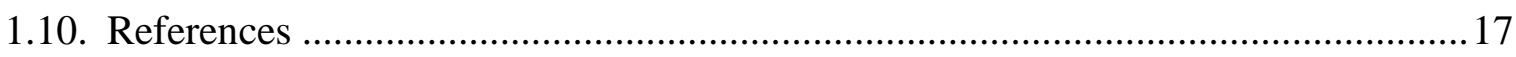

CHAPTER 2 THE INFLUENCE OF ELEVATED TEMPERATURE ON GONADAL DEVELOPMENT IN NILE TILAPIA (Oreochromis niloticus).................27

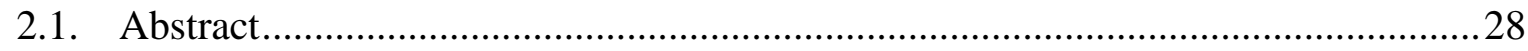

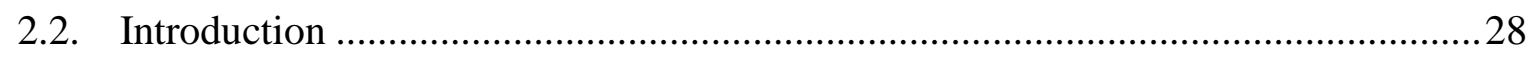

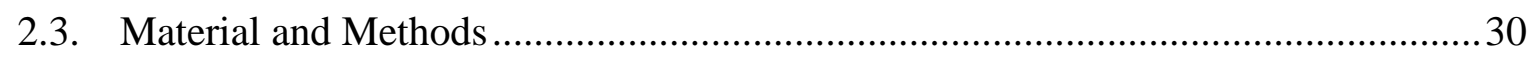

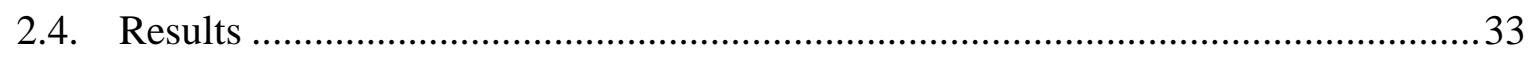

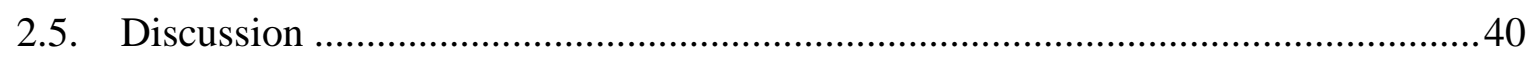

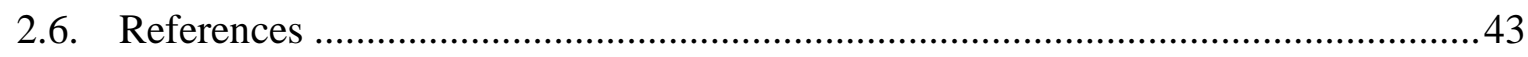




\section{CHAPTER 3 GERMLINE DEVELOPMENT OF NILE TILAPIA (Oreochromis}

niloticus) REARED UNDER DIFFERENT TEMPERATURE REGIMES

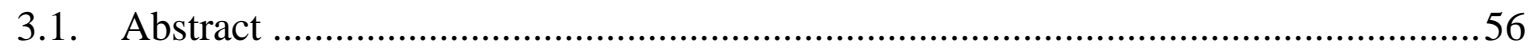

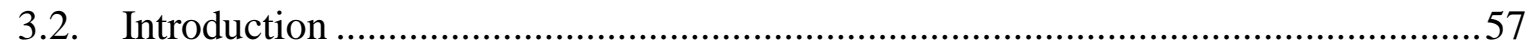

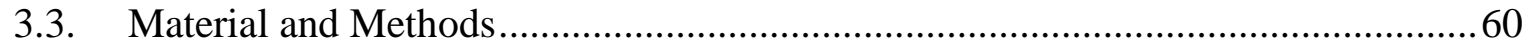

3.3.1. Experimental design, fish maintenance and sampling .....................................60

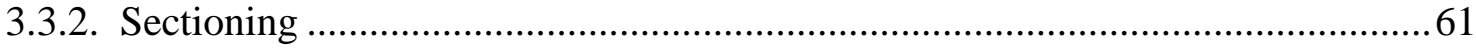

3.3.3. Immunostaining of paraffin-embedded samples..............................................62

3.3.4. Immunostaining of Polyfreeze-tissue-freezing-medium-embedded samples......62

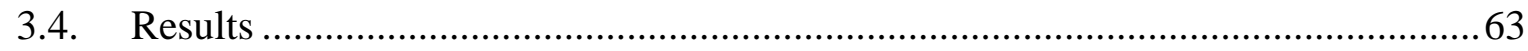

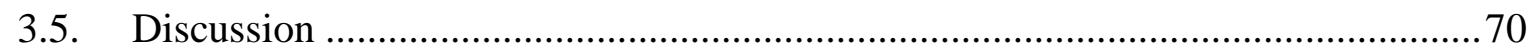

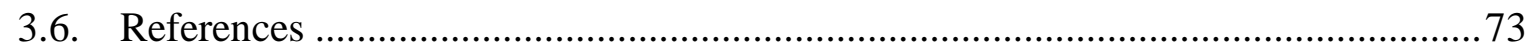

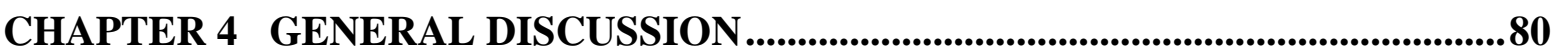

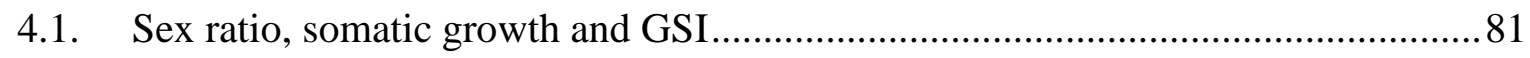

4.2. The influence of temperature treatments on ovarian development in Nile tilapia $(O$.

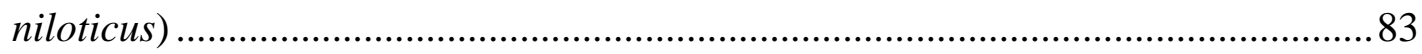

4.3. The effect of temperature treatments on ovarian germline stem cells in Nile tilapia

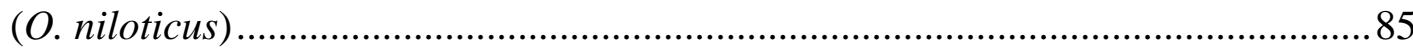

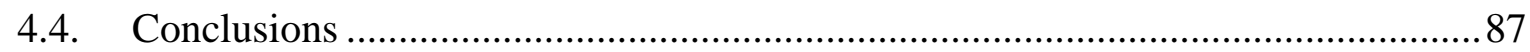

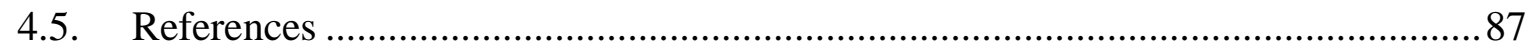

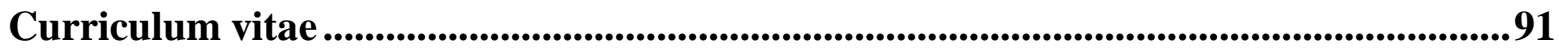




\section{List of Tables}

Table 1. Least square means and standard deviations of body mass [g], body length [cm], and GSI [\%] of temperature-treated $\left(36^{\circ} \mathrm{C}\right)$ genetically all-female Nile tilapia and their

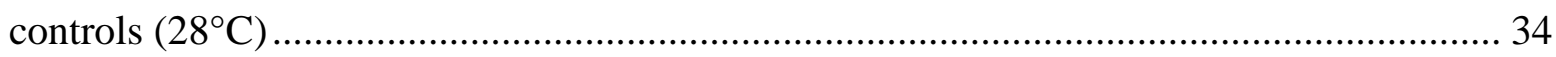

Table 2. Least square means and standard deviations of the proportion of developmental stages of oocytes (\%) at various stages of sexual development in Nile tilapia exposed to elevated temperature $\left(36^{\circ} \mathrm{C}\right)$ from 10 to $20 \mathrm{dpf}$ vs. untreated control females..................... 36 


\section{List of Figures}

Figure 1. The gonadal sex differentiation process in tilapia [Kobayashi et al., 2012]......... 10

Figure 2. Proportion (\%) of ovaries macro-morphologically classified as immature, maturing, mature, ripening or ripe of generation all-female tilapia temperature-treated (top) or not (bottom)

Figure 3. Photomicrograph of the ovarian structures $90 \mathrm{dpf}$ fish of control (A) and temperature-treated group (B). The composition of the cells is similar amongst anterior area (a), middle area (b), and posterior area (c) of the gonads of both groups. The peri-nucleolus phase oocytes dominate the ovarian structures. Oc: ovarian cavity, Bv: blood vessel, ovarian wall (arrow). HE stains. Bars: $50 \mu \mathrm{mm}$. 38

Figure 4. Photomicrograph of the ovarian structures of $120 \mathrm{dpf}$ of control (A) and temperature-treated (B) contain cortical alveolus stage oocyte (asterisk). Oc: ovarian cavity; Bv: blood vessel. HE stains. Bars $=50 \mu \mathrm{m}$

Figure 5. Photomicrograph of the ovarian structures of $150 \mathrm{dpf}$ of control (A) showing the mature ovarian features; and temperature-treated (B) shows the mature ovarian features with the different composition of oocytes stages. Oc: ovarian cavity. HE stains. Bars $=200 \mu \mathrm{m}$ (A); $100 \mu \mathrm{m}$ (B).

Figure 6. Photomicrograph of the ovarian structures of $180 \mathrm{dpf}$ of control (A) showing mature oocyte (Mo) with germinal vesicle (asterisk) and temperature-treated contain vitellogenic oocyte (v) with germinal vesicle (asterisk) (B). Oc: ovarian cavity, ovarian lamellae wall (arrowhead). HE stains. Bars $=100 \mu \mathrm{m}(\mathrm{A}) ; 50 \mu \mathrm{m}$ (B). 40

Figure 7. Vasa-PCNA immunostaining reveals ovarian lamellae in paraffin-sections as opposed to polyfreeze-tissue-freezing-medium sections in 120 day old tilapia females from control or temperature treatment group. (arrows = ovarian lamella; OC = ovarian cavity; scale bars $=50 \mu \mathrm{m}$ for all pictures).

Figure 8. Vasa-PCNA immunostaining of ovary cross sections in control and temperaturetreated female Nile tilapia at 90 dpf displays germline stem cells at the germinal epithelium of the ovigerous lamellae. (Vasa-positive staining = red; PCNA-positive staining = green; arrows = germinal epithelium of the ovigerous lamellae; OC = ovarian cavity; DAPI stained DNA blue; scale bars $=50 \mu \mathrm{m}$ for all pictures). 65

Figure 9. Vasa-PCNA immunostaining of female ovary cross sections in control and temperature-treated Nile tilapia at $90 \mathrm{dpf}$ reveals single (arrows) and nest-like clutches (asterisks) of ovarian germline stem cells. Ovaries display primary growth phase oocytes (po) and germline stem cells. (DAPI stained DNA blue; red = vasa-positive staining; green = PCNA-positive staining; nu = nucleus; scale bars $=50 \mu \mathrm{m}$ for control females; scale bars $=10 \mu \mathrm{m}$ for treatment group) 66 
Figure 10. Development of ovarian germline stem cells from juvenile (60 dpf) to adulthood (210 dpf) in control and temperature-treated Nile tilapia females. Germline stem cells (arrows) were identified by Vasa (red) -PCNA (green) immunostaining. DAPI stained DNA blue. (Scale bars $=20 \mu \mathrm{m}$ for $60 \mathrm{dpf}$; scale bars $=10 \mu \mathrm{m}$ for $90 \mathrm{dpf}$; scale bars $=20 \mu \mathrm{m}$ for $120 \mathrm{dpf}$; scale bars $=13 \mu \mathrm{m}$ for $210 \mathrm{dpf}$ tilapia from control group; scale bars $=50 \mu \mathrm{m}$ for $210 \mathrm{dpf}$ tilapia from treatment group). 67

Figure 11. Strong- and faint Vasa-PCNA expressing cells revealed by immunostaining of female ovary cross sections in control and temperature-treated Nile tilapia at $90 \mathrm{dpf}$. (arrows = strong expressing cells; asterisks = vasa-PCNA faint-expressing cells; DAPI stained DNA blue; Scale bars $=50 \mu \mathrm{m}$ for all pictures). 68

Figure 12. Testicular structure of temperature-induced pseudomale Nile tilapia at age 60 dpf, 120 dpf, and 210 dpf. Germline stem cells were identified by Vasa (red) - PCNA (green) immunostaining. (DAPI stains DNA blue; circles = lobules of the testes; scale bars $=20 \mu \mathrm{m}$ for $60 \mathrm{dpf}$ and $120 \mathrm{dpf}$; scale bars $=50 \mu \mathrm{m}$ for $210 \mathrm{dpf}$ ). 69 


\section{Summary}

Germ cells originate from progenitor cells, denominated as primordial germ cells (PGC). PGC are of extragonadal origin and migrate toward the gonad primordia where they proliferate and, in gonochoristic species, differentiate into sperm cells in males and oocytes in females. At the time of sex differentiation gonads are prone to the influence of external factors, such as the water temperature. Elevation of temperature from $28^{\circ} \mathrm{C}$ to $36^{\circ} \mathrm{C}$ during the critical time of gonadal differentiation i.e. 10 days post fertilization until 20 days post fertilization (dpf) is known to bring about masculinization in genetically female Nile tilapia.

The first study aimed at the characterization of the micro-morphology of temperaturetreated but no masculinized genetic females. A temperature treatment leads to masculinization in 37\% of genetic females. Macro-morphologically at $90 \mathrm{dpf}$ in both, the treatment and the control group immature ovaries were found. Maturation commenced at 120 dpf. Micro-morphologically five oocyte stages were found; chromatin nucleolus phase, peri-nucleolus phase, cortical alveolus stage, vitellogenic stage and mature oocyte stage. Chromatin nucleolus phase and the peri-nucleolus phase, being the primary growth phases, were represented at all age groups, whereas the advanced stages surfaced later. The cortical alveolus stage developed at $120 \mathrm{dpf}$; the vitellogenic stage at $150 \mathrm{dpf}$; mature stage at $180 \mathrm{dpf}$. There were slight individual differences in oocyte development.

The second study was conducted to identify and monitor the germline stem cells of Nile tilapia raised under different temperature regimes. They were identified with the aid of vasa and PCNA (Proliferating Cell Nuclear Antigen). Samples were sectioned after paraffin-embedding and Polly-freeze-tissue-freezing-medium-embedding. For producing sample sections the paraffin-embedding method was preferable. Ovarian germline stem cells of Nile tilapia were identified located at the germinal epithelium of ovigerous lamellae. Ovarian germline stem cells are occurring either singly or in clutches, and were found in both females that had not been masculinized by temperature treatment and untreated control females.

The identification of ovarian germline stem cells was easy at a young age but, due to development of ovigerous lamella, it was tedious in mature ovaries. In summary, this study revealed the existence of germline stem cells and their location in non-masculinized 
temperature-treated females and control females using immunostaining with vasa and PCNA. 


\section{Zussamenfassung}

Keimzellen entwickeln sich aus den sogenannten Urkeimzellen, die auch als primordiale Keimzellen (PGC) bezeichnet werden. PGC entwickeln sich während der Embryonalentwicklung und wandern dann in die Gonadenanlagen, wo sie sich vermehren und bei getrenntgeschlechtlichen Arten in Spermien in Männchen und Oozyten bei Weibchen differenzieren. Während der Geschlechtsdifferenzierung sind die Gonaden anfällig für den Einfluss externer Faktoren, wie z. B. der Wassertemperatur. Eine Erhöhung der Wassertemperatur von $28^{\circ} \mathrm{C}$ auf $36^{\circ} \mathrm{C}$ während der kritischen Phase der Geschlechtsdifferenzierung, vom 10. bis zum 20. Tag nach der Befruchtung kann zu einer Vermännlichung genetisch-weiblicher Tilapien führen.

In der ersten Studie führte eine entsprechende Temperaturbehandlung bei genetisch weiblichen Tilapien zu einem Anteil funktioneller Männchen von 37\%. Makromorphologisch konnten die Gonaden 90 Tage alter Weibchen aus Kontroll- und Behandlungsgruppen als unreife Ovarien klassifiziert werden. Erste Reifungsprozesse bis hin zur Oogenese begannen 120 Tage nach der Befruchtung. Die Oogenese konnte mikromorphologisch weiterhin in folgende Stadien eingeteilt werden: Chromatin Nukleolus, Peri-Nukleolus, kortikale Alveolus, Vitellogenese und reife Eizelle. Oozyten in den Phasen des Chromatin Nukleolus und des Peri-Nukleolus, welche auch die primäre Wachstumsphase darstellen, wurden bei weiblichen Fischen aller Altersgruppen festgestellt. Während weiter fortgeschrittenen Oozytenstadien erst ab einem Alter von 120 Tagen festgestellt werden konnten. Oozyten in der Phase des kortikalen Alveolus wurden demnach frühestens am 120. Lebenstag gefunden. In der Vitellogenese befindliche Oozyten traten erst nach 150 Tagen auf. Reife Eizellen wurden ab einem Alter von 180 dpf festgestellt. Es konnten keine signifikanten Unterschiede in der Eizellentwicklungsstadien zwischen Kontroll- und Behandlungstieren festgestellt werden.

Das Ziel der zweiten Studie war die Identifikation von Keimbahn-Stammzellen bei Tilapien, die während der Geschlechtsdifferenzierung verschiedenen Aufzuchttemperaturen ausgesetzt waren. Die Identifizierung der Keimbahn-Stammzellen erfolgte anhand von Immunohistochemie mittels Vasa und PCNA (Proliferierendes Cell Nuclear Antigen) Antikörperfärbung. Es wurden zunächst histologische Schnitte von in Paraffin eingebettetem Ovargewebe hergestellt. Keimbahn-Stammzellen wurden im Keimepithel der Ovarien identifiziert, wobei diese in einzelner, isolierter oder in Clusterform vorlagen. Keimbahn-Stammzellen wurden sowohl bei weiblichen Tieren aus 
Kontroll- als auch Behandlungsgruppen identifiziert. Zusammenfassend, konnten erstmalig Keimbahn-Stammzellen und ihre Lage in den Gonaden genetisch weiblicher Tilapien, aus Kontroll- und Behandlungsgruppen, mittels Vasa und PCNA Antikörperfärbung charakterisiert werden. 
CHAPTER 1

INTRODUCTION TO SEXUAL DEVELOPMENT OF NILE TILAPIA

(Oreochromis niloticus) 


\subsection{Foreword}

Gonad is the primary organ produces germ cells, sperm in males and oocytes in females. Progenitors of germ cells are derived from outside the gonad during the embryo stage. These cells are denominated as primordial germ cells (PGCs). PGCs have bipotential characteristics. In the ovary, they developed as oogonia and in testes they become spermatogonia [Yoshizaki et al., 2002]. Research about germ cells has gained momentum during the last decades, since the sexual developments and the production of gametes are of major importance in aquaculture species with large sexual dimorphism such as the Nile tilapia (O. niloticus).

Nile Tilapia is a gonochoristic species, in which the gonad differentiates into singular reproduction system, male produces sperm and the female produces oocytes during their lifespan [Kobayashi et al., 2012; Ijiri et al., 2008]. Furthermore, Nile tilapia is an asynchronous spawner, which are characterized by simultaneously ovaries containing several developmental stages of oocytes [Coward, and Bromage, 2000; Getinet, 2008]. Previously, De Graaf et al. [1999] described O. niloticus as a plurimodal spawner, oocytes showing different stages of vitellogenesis. Nile tilapia shows the ability to spawn all year long, producing the eggs during their whole lifespan. Unlike in mammals, where germline stem cells cannot be renewed, teleost oocyte production is supported by the ability of the renewal germline stem cells. In accordance with other teleost, adult female Nile tilapia actively produce eggs lifelong.

Tilapia is well-known to be an excellent model to study gametogenesis [Coward, and Bromage, 2000]. O. niloticus is easy to maintain, is resistant toward harsh environmental conditions [De Graaf et al., 1999] as well as frequently spawning throughout the year [Babiker, and Ibrahim, 1979]. 
Although Nile tilapia is an increasingly investigated species, the identification of germline stem cells and the sexual developmental of Nile tilapia reared at different temperatures regimes remains largely unknown. Especially the dynamics of oocyte development of females non-masculinized by temperature treatment remain unexplored.

Temperature is known to be an environmental cue which effects gonadal differentiation in Nile tilapia [Baroiller et al., 1995; Tessema et al., 2006]. Study of temperature effects on gonadal differentiation was broadly conducted. However there is lack knowledge about the identification of germline stem cells in ovarian tissues by means of elevated temperature.

\subsection{Sex determination system in tilapia}

The phenotypic sex in Nile tilapia is determined by a continuum of genetic, autosomal and temperature-dependent factors [D’Cotta et al., 2001; Baroiller et al., 2009]. Sex determination factors are important aspect for sex differentiation [Devlin, and Nagahama, 2002]. Sex determination in Nile tilapia shows a complicated process involved the major genetic factor and minor autosomal factor. Temperature as an external factor is able to alter the sex differentiation [Lühmann et al., 2012]. Wessels and Hörstgen-Schwark, [2007, 2011] identified the heritability of the temperature sensitivity among Nile tilapia families. Sex determination system in tilapia comprises genetic sex determination and temperature-dependent sex determination.

\subsubsection{Genetic sex determination}

Genetic sex determination in tilapia involves major genetic factors which can be influenced by minor autosomal factor. Microsatellites relating to sex determination have been determined in O. niloticus [Lühmann et al., 2012]. Comparison of O. niloticus families revealed sensitivity differences amongst families [Wessels, and HoerstgenSchwark, 2007]. Sex is determined by XX/XY systems in linkage group 1 (LG1) in $O$. 
niloticus. Further, genes on LG 3 and 23 and temperature are able to determine sex ratio in tilapia [Palaiokostas et al., 2015]. Regions on genes contributing to sex determination, quantitative trait loci, have been identified on linkage groups 1,3 , and 23 in various species and strains of tilapia [Shirak et al., 2006].

\subsubsection{Temperature-dependent sex determination}

Temperature is well-known to be an external cue influencing gonadal differentiation in Nile tilapia [Baroiller et al., 1995; D’Cotta et al., 2001; Tessema et al., 2006; Alvarenga, and França, 2009]. Elevated temperature $>34^{\circ} \mathrm{C}$ applied during the critical period of sex differentiation (10 to $20 \mathrm{dpf}$ ) resulted in masculinization of Nile tilapia [Tessema et al., 2006; Baroiller et al., 2009]. A temperature treatment from $10 \mathrm{dpf}$ to $20 \mathrm{dpf}$ effectively induced masculinization, while longer treatment durations were not effective [Tessema et al., 2006]. Moreover, temperature effects on the phenotypic sex were highly repeatable, heritable and can be selected in Nile tilapia [Wessels, and Hörstgen-Schwark, 2007, 2011]. Allelic variants in the Amh gene, located in LG23, have been identified which lead to autosomal and temperature dependent sex reversal [Wessels et al., 2014]. Other QTL for temperature-responsiveness have been found on LG20 [Palaiokostas et al., 2015].

\subsection{Gonadal sex differentiation of tilapia}

Nile tilapia (O. niloticus) is a gonochoristic species. Normally the gonads develop into testis or ovary and they retain this condition throughout their lifespan [Ijiri et al., 2008]. Gonads of tilapia are located at the dorsal mesentery. The gonadal primordia also denominated germinal ridge are the predecessors of the gonad. The cells establishing the germinal ridge are different from the progenitor germ cells. The germinal ridge is formed by the thickening of mesoderm and bulging along the coelomic cavity ventral to the developing kidney and lateral to the dorsal mesentery [Devlin, and Nagahama, 2002]. 
In O. niloticus, as in other gonochoristic teleost, ovarian differentiation occurs earlier than testicular differentiation. The differentiation towards the phenotypic female gonad takes place 20 days post-hatching and recognizable by the formation of an ovarian cavity. Male gonadal differentiation occur 5 days later [Kobayashi et al., 2012]. Kobayashi [2010] proposed three stages of gonadal differentiation in tilapia: 1) primordial germ cell formation commencing three days after hatching; 2) establishment of sexual dimorphism commencing nine days after hatching and characterized by large numbers of germ cells and formation of an ovarian cavity in females and intra-testicular efferent ducts in males; 3) commencement of first meiosis, 35 days after hatching in females and more than 50 days after hatching in males.

Primordial germ cells (PGC) are precursors of germ cells [Yoshizaki et al., 2002]. PGC of Nile tilapia, like in other vertebrates are formed outside the gonadal anlagen and migrate into the gonadal anlagen at 7 days-post-fertilization (dpf) [Kobayashi et al., 2003]. Undifferentiated gonads of Nile tilapia can be found at 3 days post hatching (dph) i.e. 7 dpf. The gonad is undifferentiated at this age. After migration, PGCs commence to proliferate until reaching an amount of cells and begin to differentiate. Ovarian differentiation takes place at $20 \mathrm{dph}$ while testicular differentiation takes place at $25 \mathrm{dph}$. The signs of differentiation are the ovarian cavity formation in female and intra-testicular efferent ducts in male [Kobayashi et al., 2012]. The first meiosis commences at 35 days after hatching, whereas spermatogenesis commences between 50-70 days after hatching [Nakamura et al., 1998].

During embryonic development, early germ cells migrate, and find their final destination during development by interacting with somatic cells of particular tissues [Devlin, and Nagahama, 2002]. 


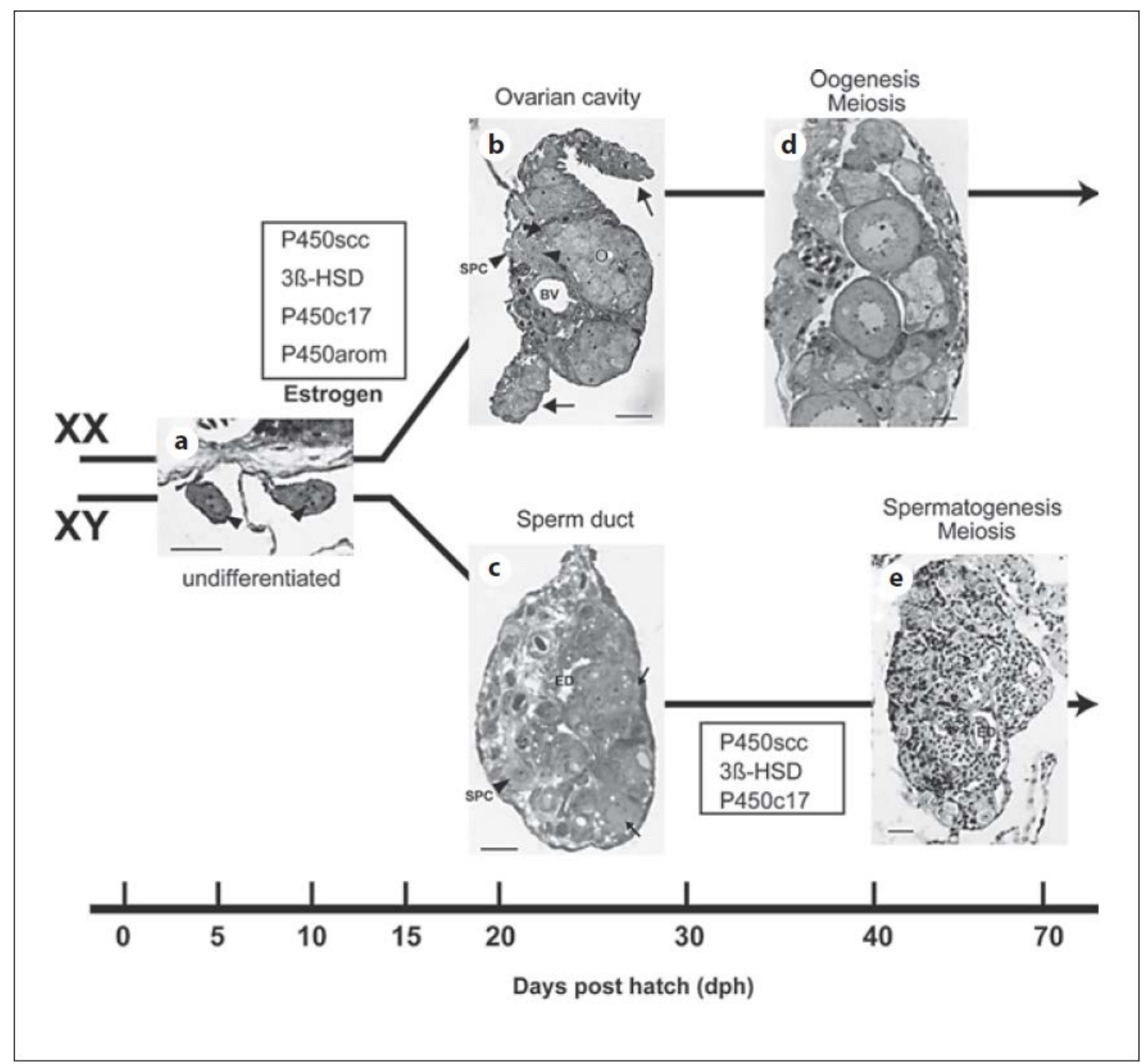

Figure 1. The gonadal sex differentiation process in tilapia [Kobayashi et al., 2012].

\subsection{Development of ovaries in tilapia}

After the differentiation of gonads, meiosis initiates oogenesis and spermatogenesis. Oogenesis occurs in the ovary, forming oocytes, while spermatogenesis takes place in the testes forming sperm cells [Kobayashi et al., 2012].

Babiker and Ibrahim [1979] classified the developmental stages of the ovary by distinctive features and oocyte stage as follows:

- Immature Ia : ovaries were primordial, the color of ovaries were flesh colored, thin and short, the gonado-somatic index (GSI) less than 0.04. Germ cells in oogonia stage with meiotic divisions in progress. 
- $\quad$ Maturing Ib : ovaries were cream colored, translucent and elongated. The oocytes were no visible. The GSI range was $0.05-0.18$. Two type primary oocytes were found i.e. small oocytes with darkly staining cytoplasm and larger oocytes at protoplasmic growth. The oocytes diameter was 30-103 $\mu$ m.

- $\quad$ Mature II: the numerous small oocytes were visible and construct a light yellow with a red hue. The GSI range was 0.19-0.60. The primary oocytes were visible as in stage I, trophoplasmic growth with peripheral cytoplasmic vacuoles. Atretic oocytes are also visible. The oocytes diameter was 483-856 $\mu \mathrm{m}$.

- $\quad$ Ripening III: various oocytes were visible and construct bright yellow color. The GSI range was $0.60-1.18$. The primary oocytes were visible in stage I and II. The oocytes were in at different stage of yolk deposition, later known as vitellogenesis. Groups of atretic oocytes were frequent. The diameter of oocytes was 690-1200 $\mu \mathrm{m}$.

- $\quad$ Ripe IV: the ovary filled almost the visceral cavity with faint yellow color. The oocytes as in the stage I and the vitellogenic oocytes, the oocytes undergo vitellogenesis. Atretic oocytes in various stages of reabsorption were emerged. The oocytes diameter was $1400-2200 \mu \mathrm{m}$.

- $\quad$ Spawning V: the appearance of ovaries like in stage IV. The difference was on oocytes diameter, i.e. 589-1137 $\mu$ m.

- $\quad$ Spent VI: the performance of ovaries return into flesh colored like in the stage I. the GSI range was $0.07-0.31$. The primary oocytes in diameter $30-171 \mu \mathrm{m}$ were filled the ovaries. The atretic oocytes were substantially visible.

Selman and Wallace [1986] determined oocyte development by the ovarian follicle size. Oocyte development is classified into primary growth, cortical alveolus stage, vitellogenesis stage, and oocyte maturation. Oocyte development is described by Selman and Wallace [1986] as follows: 
Primary Growth stage

Primary growth is the early stage which is consists of chromatin nucleolus phase and perinucleolus phase based on the nucleolar morphology. The diameter range of chromatin nucleolus phase is $8-20 \mu \mathrm{m}$. Perinucleolus phase is around $20-175$ $\mu \mathrm{m}$.

- $\quad$ Cortical Alveolus stage

The cortical alveolus stage is characterized by the appearance of cortical alveoli, zona pellucida and lipid. Cortical alveoli are membrane bound structures variable in size and structure. They contain glycoprotein synthetized by the granular endoplasmic reticulum and Golgi complex. The number and size of cortical alveoli increase as oocytes grow. Zona pellucida is a homogenous layer between oocyte and follicular cells. Lipid droplet is accumulate around the nucleus and is get bigger. Then disappear as the accumulation of yolk. The average diameter of ovarian follicles in this stage is between $175 \mu \mathrm{m}-550 \mu \mathrm{m}$.

- $\quad$ Vitellogenesis stage

Vitellogenin, a female-specific protein, is produced during the vitellogenesis stage by the liver. Vitellogenin is transported by blood stream to the ovary. Thus vitellogenin is also called exogenous yolk protein precursor. The average diameter of ovarian follicles at this stage is between $0.55 \mathrm{~mm}-1.35 \mathrm{~mm}$.

- $\quad$ Maturation Stage

The last stage before oocytes are ovulated, followed by spawning. During maturation, meiosis of the oocytes is resumed. The average diameter of ovarian follicles in this stage is between $1.35 \mathrm{~mm}-1.90 \mathrm{~mm}$.

Kronert et al. [1989] classified gonadal development based on the appearance of an ovary of Nile tilapia into six stages i.e. immature/inactive stage, inactive-active stage, active stage, active-ripe stage, ripe/ ripe-running stage and spent. 
- Immature stage/ inactive stage: there is no egg visible in the ovary.

- $\quad$ Inactive-active stage: a few eggs in the ovary, less than 20 oocytes with egg size less than $0.2 \mathrm{~mm}$.

- Active stage: more than 20 eggs in the ovary with egg size less than $0.2 \mathrm{~mm}$.

- $\quad$ Active-ripe stage: eggs in yellow color, egg size 0.2-1.1 mm.

- $\quad$ Ripe/ ripe-running stage: egg size above $1.1 \mathrm{~mm}$ in yellow color.

- $\quad$ Spent: the yolk absorption eggs is taking place, eggs become white.

\subsection{Sexual plasticity of teleost}

The unique characteristic of teleost is having sexual plasticity because of bipotential gonad characteristic [Bhandari et al., 2006]. Sexes are able to reverse from male to female or vice versa by means of environmental cues because of the high sexual plasticity of undifferentiated germ cells [Baroiller, and D’Cotta, 2001; Yoshizaki et al., 2010]. The aptitude of sex reversal in teleost is decline after gonadal differentiation occurred [Yoshizaki et al., 2010].

In hermaphroditic species, sexes are able to change naturally from female to male (protogynous) or male to female (protandrous) [Devlin, and Nagahama, 2002]. The focus of this study is tilapia, a gonochoristic teleost which is naturally not be able to sex reversed.

The external sex steroids influence masculinization or feminization in teleost, Nile tilapia [Rougeot et al., 2008]. Sun et al. [2014] reported masculinization through aromatase inhibitor treatment in differentiated females Nile tilapia. Fadrozole as aromatase inhibitor inhibited androgen conversion to estrogen. As a consequence accumulation of the androgen 11-ketotestosteron will trigger secondary sex reversal into functional testes producing fertile sperm. Furthermore, Sun et al. [2014] indicated that there was transformation during secondary sex reversal: the oogonia, located in the germinal 
epithelium, were transformed to spermatogonia. While Leydig and Sertoli cells were transdifferentiated from interstitial cells and granulosa cells. Moreover, Sun et al. [2014] indicated that transdifferentiation occurs by activation of the male pathway gene as a consequences of suppression of the female pathway gene.

Bhandari et al. [2006] treated undifferentiated genetically-female (XX) Nile tilapia with methyl-testosterone (MT) during gonadal differentiation. A MT-treatment led to altered sexual development of Nile tilapia by producing $100 \%$ male. The expression of steroidogenic enzyme was impaired after MT treatment.

\subsection{Germline stem cell renewal in teleost}

The ability to self-renewal is equal in the male or female in teleost. Adult female teleosts can continually produce eggs throughout their lifespan similar to males [Wildner et al., 2013]. In higher vertebrates such as mammals, the ability of germ cells self-renewal is only in male. Female germ cells of mammals lose their renewal ability once gonad differentiated [Spradling et al., 2011]. The sustainability of sperm production in vertebrates is supported by germline stem cells which figure at specific niche [Nakamura, 2010].

Germ cells in undifferentiated gonads are classified into type I and type II. In type I germ cells actively renew and become germline stem cells. This type of cell divides into two daughter cells each of which is surrounded by supporting cells. In type II, germ cells synchronously and successively divide, enter meiosis and commit to gametogenesis [Saito et al., 2007].

Nakamura et al. [2010] identified the germline stem cells in transgenic adult teleost medaka. This finding will encourage studies on germline stem cells. Nakamura et al. [2010] discovered germinal cradles in ovarian medaka. Germinal cradles are established by three groups of cells i.e. single isolated germ cells (Gs) as a stem cells which express 
nanos and surrounded by sox9b-expressing cells; cyst forming germ cells (Gcys) consisting of mitotic and meiotic germ cells surrounded by sox $9 b$-expressing cells; oocytes at diplotene stage and individually surrounded by sox9b-expressing cells [Nakamura et al., 2010]. The unique characteristics and pivotal roles of germline stem cells in teleost built the importance of the germline stem cells study. Unlike in mammals, studies about germline stem cells in fish remain incomplete [Lacerda et al., 2013].

\subsection{Endocrine and molecular control of sex differentiation of tilapia}

Gonadal differentiation in teleosts is controlled by genetic and various environmental factors [Nakamura et al., 1998]. Doublesex- and Mab-3-related transcription factor-1 (Dmrt1) is one of the keys of masculinization. Dmrt1 suppresses the production of aromatase. It causes estrogen conversion from testosterone to be interrupted, resulting high concentration of testosterone that induce testes formation [Wang et al., 2010]. Furthermore, Poonlaphdecha et al. [2011] found that Amh (anti-mullerian hormone) is important for sexual differentiation. Amh in brain is higher than Amh in gonads at the onset at male differentiation by $10 \mathrm{dpf}$ indicating that, likely, sexual differentiation is happening earlier in the brain of tilapia. Moreover, Wessels et al. [2014] identified an allelic variant in the Amh gene of a selected line of Nile tilapia which is a major QTL for autosomal and temperature-dependent sex reversal.

Endogenous estrogen is necessary for ovarian differentiation in O. niloticus [Nakamura et al., 2003]. The effect of an exogenous aromatase inhibitor leads to masculinization of $O$. niloticus as reported by Afonso et al. [2001]. Sexual differentiation in teleost is driven by steroid hormones, androgen led to male differentiation and estrogen led to female differentiation. Steroidogenic enzyme, p450 cytochrome aromatase, mediates the biosynthesis of estrogens from androgen. Alteration in steroid or aromatase levels may cause sex reversal [Afonso et al., 2001]. 


\subsection{PCNA and vasa as cell markers}

PCNA is a protein synthesized during the S-phase in cell cycle. It resembles cyclin, consists of $29 \mathrm{kDa}$ protein. PCNA protein is crucial for DNA replication [Kelman, 1997]. PCNA has three functions: DNA replication, DNA repairing and cell apoptosis [Paunesku et al., 2001]. PCNA existence determines the cell death or survival by three mechanisms, i.e. DNA replication when abundance of PCNA without p53 is high, DNA repairing when abundance of PCNA together with p53 existence is high, and apoptosis when the PCNA abundance is low or even absent in the cells. PCNA is important for survival of the cells [Paunesku et al., 2001].

Vasa gene is well-investigated as a germ cell marker in vertebrates [Olsen et al., 1997; Yoshizaki et al., 2000; Yoshizaki et al., 2002; Gustafson, and Wessel, 2010; Nagasawa et al., 2013]. Vasa protein was studied in zebrafish by Braat et al. [2000] and [Knaut et al., 2000]. Vasa belong to DEAD protein family [Sengoku et al., 2006]. Many researches revealed the expression of vasa gene, mRNA, and protein in teleost species [Braat et al., 2000; Gustafson, and Wessel, 2010; Knaut et al., 2000; Knaut et al., 2002; Nagasawa et al., 2013; Yoon et al., 1997; Xu et al., 2014].

Vasa expression can be detected during early germ cell fate, both in ovaries and testes. In further developed germ cells, vasa expression quickly diminishes. Vasa expression persists in the ovaries until the pre-vitellogenic stage, while in the testes, vasa expression is only strongly detected in spermatogonia [Kobayashi et al., 2000]. Furthermore, Knaut et al. [2002] observed that the vasa-RNA determines the germline cells fate.

\subsection{Objectives}

Studies on the effect of elevated temperature on gonadal differentiation to bring about masculinization have been conducted by many researches. Studies on the development in 
female tilapia that have not been masculinized by elevated temperature are lacking. Therefore this study aimed to figure out the dynamics of ovarian development of unmasculinized female tilapia, compared to control female tilapia in all-genetically female population.

The dynamics of ovarian development was studied by observations of macro and micromorphological features. These studies give insight to the development of temperaturetreated non-masculinized females and a control group and its changes by means of different temperature regimes.

The study is aimed at identifying and observing the ovarian germline stem cells in Nile tilapia (O. niloticus) and its development altered by elevated temperature. Ovarian germline stem cells of Nile tilapia were identified by studying the expression of vasa and PCNA proteins. Ovarian germline stem cells niche was observed as well. The study was conducted at consecutives ages of fish to study ovarian germline stem cells in immature and mature ovaries.

\subsection{References}

Afonso LO, Wassermann GJ, Terezinha de Oliveira R: Sex reversal in Nile tilapia (Oreochromis niloticus) using a nonsteroidal aromatase inhibitor. J Exp. Zool. 290:177-181 (2001).

Alvarenga ER de, França LR de: Effects of different temperatures on testis structure and function, with emphasis on somatic cells, in sexually mature Nile Tilapias (Oreochromis niloticus). Biol. Reprod. 80:537-544 (2009).

Babiker MM, Ibrahim H: Studies on the biology of reproduction in the cichIid Tilapia nilotica (L.): gonadal maturation and fecundity. J. Fish. Biol. 14:437-448 (1979). 
Baroiller J-F, Chourrout D, Fostier A, Jalabert B: Temperature and sex chromosomes govern sex ratios of the mouthbrooding Cichlid fish (Oreochromis niloticus). J. Exp. Zool. 273:216-223 (1995).

Baroiller JF, D’Cotta H, Bezault E, Wessels S, Hoerstgen-Schwark G: Tilapia sex determination: Where temperature and genetics meet. Comp. Biochem. Physiol. - A Mol. Integr. Physiol. 153:30-38 (2009).

Baroiller JF, D’Cotta H: Environment and sex determination in farmed fish, in : Comparative Biochemistry and Physiology - C Toxicology and Pharmacology (2001), pp 399-409.

Bhandari RK, Nakamura M, Kobayashi T, Nagahama Y: Suppression of steroidogenic enzyme expression during androgen-induced sex reversal in Nile tilapia (Oreochromis niloticus). Gen. Comp. Endocrinol 145:20-24 (2006).

Braat AK, Van De Water S, Goos H, Bogerd J, Zivkovic D: Vasa protein expression and localization in the zebrafish. Mech. Dev. 95:271-274 (2000).

Coward K, Bromage NR: Reproductive physiology of female tilapia broodstock. Rev. Fish. Biol. Fish 10:1-25 (2000).

D’Cotta H, Fostier a, Guiguen Y, Govoroun M, Baroiller JF: Aromatase plays a key role during normal and temperature- induced sex differentiation of Tilapia Oreochromis niloticus. Mol. Reprod. Dev. 59:265-276 (2001).

De Graaf GJ, Galemoni F, Huisman EA: Reproductive biology of pond reared Nile tilapia, Oreochromis niloticus L. Aquac. Res. 30:25-33 (1999). 
Devlin RH, Nagahama Y: Sex determination and sex differentiation in fish: An overview of genetic, physiological, and environmental influences. Aquaculture 208:191-364 (2002).

Getinet, G. Tsadik (Ethiopian Institute of Agricultural Research NAC: Effects of Maternal Age on Fecundity, Spawning Interval, and Egg Quality of Nile tilapia, Oreochromis niloticus (L.). J World Aquac. Soc. 39:671-677 (2008).

Grier $\mathrm{H}$ : Ovarian germinal epithelium and folliculogenesis in the common snook, Centropomus undecimalis (Teleostei: Centropomidae). J Morphol. 243:265-281 (2000).

Grier HJ, Uribe MC, Parenti LR: Germinal epithelium, folliculogenesis, and postovulatory follicles in ovaries of rainbow trout, Oncorhynchus mykiss (Walbaum, 1792) (Teleostei, Protacanthopterygii, Salmoniformes). J Morphol. 268:293-310 (2007).

Gustafson EA, Wessel GM: Vasa genes: Emerging roles in the germ line and in multipotent cells. BioEssays 32:626-637 (2010).

Hanna CB, Hennebold JD: Ovarian germline stem cells: An unlimited source of oocytes? Fertil Steril 101:20-30 (2014).

Hattori RS, Gould RJ, Fujioka T, Saito T, Kurita J, Strüssmann CA, et al.: Temperaturedependent sex determination in Hd-rR medaka Oryzias latipes: Gender sensitivity, thermal threshold, critical period, and DMRT1 expression profile. Sex. Dev. 1:138146 (2007).

Hayashi Y, Kobira H, Yamaguchi T, Shiraishi E, Yazawa T, Hirai T, et al.: High temperature causes masculinization of genetically female medaka by elevation of cortisol. Mol. Reprod. Dev. 77:679-686 (2010). 
Ijiri S, Kaneko H, Kobayashi T, Wang DS, Sakai F, Paul-Prasanth B, et al.: Sexual dimorphic expression of genes in gonads during early differentiation of a teleost fish, the Nile tilapia Oreochromis niloticus. Biol. Reprod. 78:333-341 (2008).

Ito LS, Takahashi C, Yamashita M, Strüssmann CA: Warm Water Induces Apoptosis, Gonadal Degeneration, and Germ Cell Loss in Subadult Pejerrey Odontesthes bonariensis (Pisces, Atheriniformes). Physiol. Biochem. Zool. 81:762-774 (2008).

Kelman Z: PCNA : structure, functions and interactions (1997).

Knaut H, Pelegri F, Bohmann K, Schwarz H, Nüsslein-Volhard C: Zebrafish vasa RNA but not its protein is a component of the germ plasm and segregates asymmetrically before germline specification. J. Cell. Biol. 149:875-888 (2000).

Knaut H, Steinbeisser H, Schwarz H, Nüsslein-Volhard C: An evolutionary conserved region in the vasa $3^{\prime}$ UTR targets RNA translation to the germ cells in the zebrafish. Curr. Biol. 12:454-466 (2002).

Kobayashi T, Ishibashi R, Yamamoto S, Otani S, Ueno K, Murata O: Gonadal morphogenesis and sex differentiation in cultured chub mackerel, Scomber japonicus. Aquac. Res. 42:230-239 (2011).

Kobayashi T, Kajiura-Kobayashi H, Nagahama Y: Differential expression of vasa homologue gene in the germ cells during oogenesis and spermatogenesis in a teleost fish, tilapia, Oreochromis niloticus. Mech. Dev. 99:139-142 (2000).

Kobayashi T, Kajiura-Kobayashi H, Nagahama Y: Germ cells during gonadal sex differentiation in the teleost. Fish Physiol. Biochem. 28:157 (2003).

Kobayashi T: In vitro germ cell differentiation during sex differentiation in a teleost fish. Int. J. Dev. Biol. 54:105-112 (2010). 
Kobayashi Y, Nagahama Y, Nakamura M: Diversity and plasticity of sex determination and differentiation in fishes. Sex. Dev. 7:115-125 (2012).

Kronert U, Hörstgen-Schwark G, Langholz HJ: Prospects of selecting for late maturity in tilapia (Oreochromis niloticus). I. Family studies under laboratory conditions. Aquaculture 77:113-121 (1989).

Lacerda SMSN, Costa GMJ, Campos-Junior PHA, Segatelli TM, Yazawa R, Takeuchi Y, et al.: Germ cell transplantation as a potential biotechnological approach to fish reproduction. Fish Physiol. Biochem. 39:3-11 (2013).

Lee KH, Yamaguchi A, Rashid H, Kadomura K, Yasumoto S, Matsuyama M: Germ cell degeneration in high-temperature treated pufferfish, Takifugu rubripes. Sex. Dev. 3:225-232 (2009).

Lühmann LM, Knorr C, Hörstgen-Schwark G, Wessels S: First evidence for familyspecific QTL for temperature-dependent sex reversal in Nile tilapia (Oreochromis niloticus). Sex. Dev. 6:247-256 (2012).

Nagasawa K, Fernandes JMO, Yoshizaki G, Miwa M, Babiak I: Identification and migration of primordial germ cells in Atlantic salmon, Salmo salar: Characterization of Vasa, Dead End, and Lymphocyte antigen 75 genes. Mol. Reprod. Dev. 80:118-131 (2013).

Nakamura M, Bhandari RK, Higa M: The role estrogens play in sex differentiation and sex changes of fish. Fish Physiol. Biochem. 28:113-117 (2003).

Nakamura M, Kobayashi T, Chang XT, Nagahama Y: Gonadal sex differentiation in teleost fish. J. Exp. Zool. 281:362-372 (1998). 
Nakamura M, Takahashi H: Sex differentiation in Tilapia mossambica, with special regard to the time of estrogen treatment effective in inducing complete feminization of genetic males [Internet]. Bull. Fac. Fish Hokkaido Univ. 24:1-13 (1973).

Nakamura S, Kobayashi K, Nishimura T, Higashijima S -i., Tanaka M: Identification of Germline Stem Cells in the Ovary of the Teleost Medaka. Science (80- ) 328:15611563 (2010).

Nakamura S, Kobayashi K, Nishimura T, Tanaka M: Ovarian germline stem cells in the teleost fish, medaka (Oryzias latipes). Int. J. Biol. Sci. 7:403-409 (2011).

Nakamura S: Identification of Germline Stem Cells 1561 (2010). DOI: 10.1126/science.1185473

Okutsu T, Suzuki K, Takeuchi Y, Takeuchi T, Yoshizaki G: Testicular germ cells can colonize sexually undifferentiated embryonic gonad and produce functional eggs in fish. Proc. Natl. Acad. Sci. U S A 103:2725-2729 (2006).

Olsen LC, Aasland R, Fjose A: A vasa-like gene in zebrafish identifies putative primordial germ cells. Mech. Dev. 66:95-105 (1997).

Palaiokostas C, Bekaert M, Khan MGQ, Taggart JB, Gharbi K, McAndrew BJ, et al.: A novel sex-determining QTL in Nile tilapia (Oreochromis niloticus). BMC Genomics 16:171 (2015).

Paunesku T, Mittal S, Protić M, Oryhon J, Korolev S V, Joachimiak A, et al.: Proliferating cell nuclear antigen (PCNA): ringmaster of the genome. Int. J. Radiat. Biol. 77:1007-1021 (2001). 
Pfennig F, Kurth T, Meissner S, Standke A, Hoppe M, Zieschang F, et al.: The social status of the male Nile tilapia (Oreochromis niloticus) influences testis structure and gene expression. Reproduction 143:71-84 (2012).

Poonlaphdecha S, Pepey E, Huang SH, Canonne M, Soler L, Mortaji S, et al.: Elevated amh gene expression in the brain of male tilapia (Oreochromis niloticus) during testis differentiation. Sex. Dev. 5:33-47 (2011).

Raz E: Primordial germ-cell development: the zebrafish perspective. Nat. Rev. Genet. 4:690-700 (2003).

Rougeot C, Kanfitine SY, Prignon C, Gennotte V, Mélard C: Early sex reversal during embryonic development in the Nile tilapia. Cybium 32:104-105 (2008).

Saito D, Morinaga C, Aoki Y, Nakamura S, Mitani H, Furutani-Seiki M, et al.: Proliferation of germ cells during gonadal sex differentiation in medaka: Insights from germ cell-depleted mutant zenzai. Dev. Biol. 310:280-290 (2007).

Selim KM, Shinomiya A, Otake H, Hamaguchi S, Sakaizumi M: Effects of high temperature on sex differentiation and germ cell population in medaka, Oryzias latipes. Aquaculture 289:340-349 (2009).

Selman K, Wallace RA: Gametogenesis in Fundulus heteroclitus. Integr. Comp. Biol. 26:173-192 (1986).

Sengoku T, Nureki O, Nakamura A, Kobayashi S, Yokoyama S: Structural Basis for RNA Unwinding by the DEAD-Box Protein Drosophila Vasa. Cell 125:287-300 (2006).

Shirak A, Seroussi E, Cnaani A, Howe AE, Domokhovsky R, Zilberman N, et al.: Amh and Dmrta2 genes map to tilapia (Oreochromis spp.) linkage group 23 within 
quantitative trait locus regions for sex determination. Genetics 174:1573-1581 (2006).

Siegfried KR, Nüsslein-Volhard C: Germ line control of female sex determination in zebrafish. Dev. Biol. 324:277-287 (2008).

Slanchev K: Molecular mechanisms governing germ line development in zebrafish and the role of this lineage in sexual differentiation [Internet]. Dev. Biol. (2005). Available from: http://webdoc.sub.gwdg.de/diss/2006/slanchev/

Spradling A, Fuller MT, Braun RE, Yoshida S: Germline stem cells. Cold Spring Harb Perspect Biol. 3:a002642 (2011).

Strome S, Updike D: Specifying and protecting germ cell fate. Nat Rev Mol. Cell. Biol. 16:406-16 (2015).

Sun LN, Jiang XL, Xie QP, Yuan J, Huang BF, Tao WJ, et al.: Transdifferentiation of differentiated ovary into functional testis by long-term treatment of aromatase inhibitor in Nile tilapia. Endocrinology 155:1476-1488 (2014).

Tessema M, Müller-Belecke A, Hörstgen-Schwark G: Effect of rearing temperatures on the sex ratios of Oreochromis niloticus populations. Aquaculture 258:270-277 (2006).

Uchida D, Yamashita M, Kitano T, Iguchi T: An aromatase inhibitor or high water temperature induce oocyte apoptosis and depletion of P450 aromatase activity in the gonads of genetic female zebrafish during sex-reversal. Comp. Biochem. Physiol. A Mol. Integr. Physiol. 137:11-20 (2004).

Wang DS, Zhou LY, Kobayashi T, Matsuda M, Shibata Y, Sakai F, et al.: Doublesex- and Mab-3-related transcription factor-1 repression of aromatase transcription, a 
possible mechanism favoring the male pathway in Tilapia. Endocrinology 151:1331-1340 (2010).

Wessels S, Hoerstgen-Schwark G: Selection experiments to increase the proportion of males in Nile tilapia (Oreochromis niloticus) by means of temperature treatment. Aquaculture 272:S80-S87 (2007).

Wessels S, Hoerstgen-Schwark G: Temperature dependent sex ratios in selected lines and crosses with a YY-male in Nile tilapia (Oreochromis niloticus). Aquaculture 318:79-84 (2011).

Wessels S, Hörstgen-Schwark G: Selection experiments to increase the proportion of males in Nile tilapia (Oreochromis niloticus) by means of temperature treatment. Aquaculture 272 (2007). DOI: 10.1016/j.aquaculture.2007.08.009

Wessels S, Hörstgen-Schwark G: Temperature dependent sex ratios in selected lines and crosses with a YY-male in Nile tilapia (Oreochromis niloticus). Aquaculture 318:79-84 (2011).

Wessels S, Sharifi RA, Luehmann LM, Rueangsri S, Krause I, Pach S, et al.: Allelic variant in the anti-müllerian hormone gene leads to autosomal and temperaturedependent sex reversal in a selected Nile tilapia line. PLoS One 9 (2014). DOI: 10.1371/journal.pone.0104795

Wildner DD, Grier H, Quagio-Grassiotto I: Female germ cell renewal during the annual reproductive cycle in Ostariophysians fish. Theriogenology 79:709-724 (2013).

Wong T-T, Saito T, Crodian J, Collodi P: Zebrafish germline chimeras produced by transplantation of ovarian germ cells into sterile host larvae. Biol. Reprod. 84:11901197 (2011). 
Xu H, Lim M, Dwarakanath M, Hong Y: Vasa identifies germ cells and critical stages of oogenesis in the Asian seabass. Int. J. Biol. Sci. 10:225-235 (2014).

Yoon C, Kawakami K, Hopkins N: Zebrafish vasa homologue RNA is localized to the cleavage planes of 2- and 4-cell-stage embryos and is expressed in the primordial germ cells. [Internet]. . Development 124:3157-65 (1997).

Yoshizaki G, Ichikawa M, Hayashi M, Iwasaki Y, Miwa M, Shikina S, et al.: Sexual plasticity of ovarian germ cells in rainbow trout. Development 137:1227-30 (2010).

Yoshizaki G, Takeuchi Y, Kobayashi T, Ihara S, Takeuchi T: Primordial germ cells: The blueprint for a piscine life. Fish Physiol. Biochem. 26:3-12 (2002).

Yoshizaki G, Takeuchi Y, Sakatani S, Takeuchi T: Germ cell-specific expression of green fluorescent protein in transgenic rainbow trout under control of the rainbow trout vasa-like gene promoter. Int. J. Dev. Biol. 44:323-326 (2000). 
CHAPTER 2

THE INFLUENCE OF ELEVATED TEMPERATURE ON GONADAL DEVELOPMENT IN NILE TILAPIA (Oreochromis niloticus) 


\subsection{Abstract}

Tilapia is a gonochoristic species showing an enormous plasticity in its sex determining mechanism. Besides sex chromosomes on LG1 or LG 23, autosomal and external factors such as temperature can lead to expression of the phenotypic sex. Gonadal development is the key to a species's sustainability. Elevated temperatures applied during sex differentiation are known to exhibit masculinizing effects in genetic female individuals. However, little is known about the dynamics of gonad development of females that received a temperature treatment but were not masculinized. The present study aims at giving insights into to the dynamics of gonadal development in a genetically all-female fish exposed to elevated temperature during sex differentiation, at age 10 to $20 \mathrm{dpf}$. Morphometric parameters in temperature-treated $\left(36^{\circ} \mathrm{C}, 10\right.$ days $)$ and control $\left(28^{\circ} \mathrm{C}\right)$ fish were assessed during defined stages of gonad development. Mean gonado-somatic index was higher in the control group when compared to the temperature-treated group ( $\mathrm{P}>0.05)$. In contrast, elevated temperature $\left(36^{\circ} \mathrm{C}\right.$ from 10 to $\left.20 \mathrm{dpf}\right)$ enhanced somatic growth. The macro-morphological and histological investigation of gonadal cross sections covering the period from late sex differentiation to adulthood showed subtle difference between unmasculinized temperature-treated females and control females.

Key Words: gonadal development, Nile tilapia, elevated temperature

\subsection{Introduction}

In the piscine world, based on the development of the gonads, species are classified as hermaphroditic or gonochoric. Hermaphroditic species produce sperm cells and oocytes either simultaneously or, following sex reversal, sequentially (Devlin and Nagahama, 2002). In protandrous species gonads are converted from male to female; in protogynous species from female to male. Gonochoric species, on the other hand, will, once they have 
differentiated, retain a singular type of gonad throughout their lifetime. In Oreochromis niloticus, being a gonochoric species, differentiation towards the phenotypic female gonad takes place 20 days post-hatching and is recognizable as such by the formation of an ovarian cavity. Male gonadal differentiation takes place five days later [Kobayashi et al., 2012]. Kobayashi [2010] proposed three stages of gonadal differentiation in Tilapia: 1) primordial germ cell formation commencing three days after hatching, 2) establishment of sexual dimorphism commencing nine days after hatching and characterized by large numbers of germ cells and formation of an ovarian cavity in females and intra-testicular efferent ducts in males and 3) commencement of first meiosis 35 days after hatching in females and more than 50 days after hatching in males.

Besides sex chromosomes on LG1 or LG23, autosomal and external factors such as temperature can affect expression of phenotypic sex. At the time of gonadal differentiation, sex determination can be reversed by external cues [Nakamura, and Takahashi, 1973]. An elevation of temperature from $28{ }^{\circ} \mathrm{C}$ to $36{ }^{\circ} \mathrm{C}$ during the critical period of gonadal differentiation can lead to masculinization [Baroiller et al., 1995; D’Cotta et al., 2001; Tessema et al., 2006]. Tessema et al. [2006] showed that masculinization of Nile tilapia by means of elevated water temperature can be effectuated between 10 and 20 days post fertilization.

Although the genetic orchestra leading to temperature-dependent sex reversal is largely unknown, it is well established that gonadal differentiation is mediated via hormones [Strüssmann, and Nakamura, 2002].

Aromatase is known to be an important agent in the context of ovarian differentiation in mediating the conversion of testosterone to estrogen. Although the influence of temperature on the sexual fate of Nile tilapia has been thoroughly investigated, little is known about the dynamics of ovarian development in females non-masculinized by 
temperature treatment. The present study addresses the effect of temperature on the dynamics of ovarian development at macro- and micro-morphological level.

\subsection{Material and Methods}

The tilapia (Oreochromis niloticus) used in the present study were originally derived from Lake Manzala and belonged to a population reared at the Division of Aquaculture and Water Ecology of the Department of Animal Science at Goettingen University. The specimens used in the present experiment had been produced by assisted reproduction [Lühmann et al., 2012]. To obtain genetically all-female (XX) progeny, fry was produced by fertilizing eggs from five females with sperm from a single sex-reversed XX male from a subpopulation selected for high temperature sensitivity [Lühmann et al., 2012; Wessels et al., 2014].

Eggs were obtained by hand-stripping ripe females anesthetized in water containing 20$100 \mathrm{mg} / \mathrm{l}$ cloves oil (Roth, Karlsruhe, Germany). The abdomen was gently squeezed toward the genital papilla and the eggs were collected in a bowl containing a $0.9 \%$ saline solution. Males were stripped in a similar way, though without anesthesia. Eggs and milt were mixed, water was added and the inseminated eggs were incubated as described by Oldorf et al. [1989]. Ten days post insemination, hatched fry was randomly allocated to a control and a temperature-treatment group, both being distributed to three separate tanks (110 fry per tank) serving as replicates.

Control fry was maintained at the standard temperature of $28{ }^{\circ} \mathrm{C}$, whereas temperaturetreated fry was exposed to water temperature of $36{ }^{\circ} \mathrm{C}$ from 10 to $20 \mathrm{dpf}$, the critical time for gonadal differentiation [Tessema et al., 2006]. Further rearing until $240 \mathrm{dpf}$ took place

at $28{ }^{\circ} \mathrm{C}$. Fry were initially fed a starter diet containing $48 \%$ crude protein, (Tetra Mini Baby, main feed for ornamental fish below $1 \mathrm{~cm}$ length, Tetra Company), beginning at the onset of temperature treatment as suggested by Tessema et al. [2006]. Fish were fed twice 
daily, receiving a ration containing $40 \%$ crude protein (commercial pelleted diet, Skretting C-2 pro AquaK18 Norway). Maintenance and handling of experimental fish were in accordance with the procedures customary at the Division of Aquaculture and Water Ecology of Goettingen University [Kronert et al., 1989; Oldorf et al., 1989]. The warm water recirculation facility was characterized by the following parameters: temperature = 24.1 to $29.0{ }^{\circ} \mathrm{C}, \mathrm{pH}=6.5$ to $7.0, \mathrm{NH}_{4}{ }^{+}=0.06$ to $4.60 \mathrm{mg} / \mathrm{L}$ and $\mathrm{NO}_{2}{ }^{-}=0.13$ to $2.90 \mathrm{mg} / \mathrm{L}$. From 90 dpf to 240 dpf, every 30 days 24 randomly selected fish from either group were sacrificed by exposing them to water containing $0.06 \%$ ethylene glycol mono-phenyl ether. Body mass and length were recorded and gonads were carefully dissected out. From age $90 \mathrm{dpf}$ onward, gonads were weighed on a scale with accuracy $0.001 \mathrm{~g}$ to assess the gonado-somatic index (GSI); gonads of earlier stages were too small for weight determination. Macro-morphological features were observed. The ovarian stages were classified as suggested by Babiker and Ibrahim [1979]. Up to age 120 dpf, whole gonads were processed; at more advanced stages, sections from the central portion of the organ were taken. To compare left and right gonad, both gonads were histologically processed from 90 to 120 dpf. Since no differences were found (Fig. 3), from 120 dpf onward only one gonad was processed from each six females per developmental stage.

For histological processing tissue samples were fixated overnight in $4 \%$ paraformaldehyde in $0.1 \mathrm{M}$ phosphate-buffered saline (PBS) (6.789 g NaCl, $1.478 \mathrm{~g} \mathrm{Na}_{2} \mathrm{HPO}_{4}, 0.430 \mathrm{~g}$ $\mathrm{KH}_{2} \mathrm{PO}_{4}$ in1 L water) at $4{ }^{\circ} \mathrm{C}$. After fixation, samples were rinsed with PBS, dehydrated by passaging them through successive baths of increasing concentrations of ethanol (70 \%, $80 \%, 90 \%, 100 \%, 100 \%$ ), cleared in three successive xylene baths (30 min, 45 min, 45 min), infiltrated with paraffin (paraplast-plus, melting point $56{ }^{\circ} \mathrm{C}$ ) for 30 minutes and, again, for $7 \mathrm{~h}$, followed by embedding in paraplast-plus. Samples were serially sectioned at $7 \mu \mathrm{m}$ with a Leica RM 2245 microtome. Every other section was stained with hematoxylin-eosin. Oocyte stages were classified microscopically at 5 to $40 x$ according to 
Treasurer and Holliday [1981] and Selman and Wallace [1986]. At least 500 oocytes per ovary in which nuclei were visible were classified.

Body length, body mass and GSI data were analyzed by ANOVA with the glm procedure of SAS version 9.3 (SAS Institute, 2000) using the following model:

$y_{i j k l}=\mu+T_{i}+S_{j}+A_{k}+T_{i j}+T_{i k}+S_{j k}+T S A_{i j k}+e_{i j k l}$

where $\mathrm{y}$ is the dependent variable, $\mu$ is the general mean, $T_{i}$ is the main effect of temperature (increased temperature or control), $S_{j}$ is the main effect of sex (male or female), $A_{k}$ is the main effect of age $(90,120,150,180$ or 210 days), TS, TA, SA and TSA are the interactions between the main effects, and $e_{i j k l}$ is the random error. Means for fixed effects were estimated using the LSMEANS statement. Significant differences $(\mathrm{P} \leq 0.05)$ among LSMEANS were assessed using Tukey’s adjusted pairwise comparisons.

The statistical analysis of the proportion of various developmental oocyte stages was carried out using a linear logistic model with a binary response variable, which was modeled as a binomial random variable $\left(\mathrm{y}_{\mathrm{i}}\right)$.

The dependent variable $\left(\mathrm{y}_{\mathrm{i}}\right)$ could be 1 or 0 with a probability for being or not being at a particular stage of development. The data were then analyzed with Procedure GLIMMIX of SAS using the following generalized linear model:

$$
\operatorname{Logit}\left(\pi_{\mathrm{ij}}\right)=\log \left(\pi_{\mathrm{ijk}} / 1-\pi_{\mathrm{ij}}\right)=\varphi+\mathrm{T}_{\mathrm{i}}+\mathrm{A}_{\mathrm{j}}+\mathrm{TA}_{\mathrm{ij}}
$$

where $\pi_{\mathrm{ij}}$ is the probability for being at a particular stage of development; $\varphi$ is the overall mean effect; $T_{i}$ is the main effect of temperature (increased temperature or control), $A_{j}$ is the main effect of age $(90,120,150,180$ and $210 \mathrm{dpf})$ and TA is the fixed effects of interaction.

First, least square means were estimated on the logit scale and then back-transformed using the inverse link function $\pi=\exp (x \beta) /[1+\exp (\mathrm{x} \beta)]$ to the original scale. Significant differences between least square means were tested using Tukey's adjusted pairwise 
comparisons in the LS means statement. Standard errors of least square means were calculated as described by Littell et al. [1996].

\subsection{Results}

The temporary elevation of temperature from $28^{\circ} \mathrm{C}$ to $36^{\circ} \mathrm{C}$ between ages 10 to $20 \mathrm{dpf}$ resulted in a proportion of $37 \%$ masculinized females (Table 1). In the untreated control group no phenotypic males were found. Body mass and length of either group were virtually identical at the outset. With time, temperature-treated females grew slightly faster than the untreated controls, the difference in body length reaching significance by age 240 dpf $(\mathrm{P}<0.05)$. Masculinized fish grew significantly faster than fish of either female group, the difference in body mass reaching significance by age $210 \mathrm{dpf}(\mathrm{P}<0.05)$. The age related increase in the gonado-somatic index (GSI) progressed at a slightly faster rate in control females than in temperature-treated females. From 180 dpf onward, in both phenotypic female groups the GSI increased more rapidly than in phenotypic males $(\mathrm{P}<0.05)$.

The macro-morphological appearance of the ovaries of immature females was one of thin, threadlike structures with no discernible oocytes. With increasing age, associated with advancing maturation, ovaries increased in size and assumed a-flesh-colored appearance. At age $90 \mathrm{dpf}$ ovaries of both treatment groups were still immature. At $120 \mathrm{dpf}$ three maturation stages were discernible; the first was characterized by cream colored with no oocytes visible, the second by numerous small oocytes visible with light yellow colored, the final stage by oocytes that had reached final size and were bright yellow in color. At 150 dpf, some fish had oocytes of mature size and dull yellow color. By age $210 \mathrm{dpf}$ ovaries were ripe and fish were ready to spawn. 
Table 1. Least square means and standard deviations of body mass [g], body length [cm], and GSI [\%] of temperature-treated (36 $\left.{ }^{\circ} \mathrm{C}\right)$ genetically all-female Nile tilapia and their controls $\left(28^{\circ} \mathrm{C}\right)$

\begin{tabular}{|c|c|c|c|c|c|c|c|c|c|c|c|c|c|}
\hline \multirow[t]{3}{*}{ Trait } & \multirow{3}{*}{$\begin{array}{l}\text { Phenotypic } \\
\text { sex }\end{array}$} & \multirow{3}{*}{$\begin{array}{l}\text { Number } \\
\text { of fish }\end{array}$} & \multirow{3}{*}{$\begin{array}{c}\text { Temperature } \\
\text { treatment } \\
{\left[{ }^{\circ} \mathrm{C}\right]}\end{array}$} & \multicolumn{10}{|c|}{ Age (dpf) } \\
\hline & & & & \multicolumn{2}{|c|}{120} & \multicolumn{2}{|c|}{150} & \multicolumn{2}{|c|}{180} & \multicolumn{2}{|c|}{210} & \multicolumn{2}{|c|}{240} \\
\hline & & & & Mean & SD & Mean & SD & Mean & SD & Mean & SD & Mean & SD \\
\hline \multirow{3}{*}{$\begin{array}{c}\text { Body } \\
\text { mass } \\
{[\mathrm{g}]}\end{array}$} & Male & 45 & 36 & $21.8^{\mathrm{aC}}$ & 9.3 & $49.1^{\mathrm{aC}}$ & 9.3 & $56.4^{\mathrm{aC}}$ & 11.4 & $110.5^{\mathrm{aB}}$ & 6.1 & $173.2^{\mathrm{aA}}$ & 5.9 \\
\hline & Female & 75 & 36 & $16.0^{\mathrm{aD}}$ & 5.4 & $31.1^{\mathrm{aCD}}$ & 5.4 & $45.0^{\mathrm{aC}}$ & 5.1 & $77.4^{\mathrm{bB}}$ & 7.2 & $119.2^{\mathrm{bA}}$ & 8.1 \\
\hline & Female & 120 & 28 & $15.4^{\text {a D }}$ & 4.6 & $30.6^{\mathrm{aC}}$ & 4.6 & $42.3^{\mathrm{aC}}$ & 4.6 & $66.8^{\text {bB }}$ & 4.6 & $105.4^{\mathrm{bA}}$ & 4.5 \\
\hline \multirow{3}{*}{$\begin{array}{l}\text { Body } \\
\text { length } \\
{[\mathrm{cm}]}\end{array}$} & Male & 45 & 36 & $10.4^{\mathrm{aC}}$ & 1.0 & $13.6^{\mathrm{aCB}}$ & 1.0 & $14.0^{\mathrm{aBD}}$ & 1.2 & $17.4^{\mathrm{aAD}}$ & 0.6 & $20.3^{\mathrm{aA}}$ & 0.6 \\
\hline & Female & 75 & 36 & $9.4^{\mathrm{aC}}$ & 0.5 & $11.7^{\mathrm{aCB}}$ & 0.5 & $13.0^{\mathrm{aB}}$ & 0.5 & $15.1^{\mathrm{aD}}$ & 0.8 & $17.6^{\mathrm{aAD}}$ & 0.8 \\
\hline & Female & 120 & 28 & $9.4^{\mathrm{aC}}$ & 0.5 & $11.6^{\mathrm{aCB}}$ & 0.5 & $12.8^{\mathrm{aB}}$ & 0.5 & $15.8^{\mathrm{aD}}$ & 0.5 & $16.9^{\mathrm{bD}}$ & 0.5 \\
\hline GSI & Male & 45 & 36 & $0.2^{\mathrm{aC}}$ & 0.5 & $0.4^{\mathrm{aC}}$ & 0.4 & $0.3^{\mathrm{aC}}$ & 0.5 & $0.9^{\mathrm{aC}}$ & 0.3 & $1.6^{\mathrm{aCB}}$ & 0.2 \\
\hline \multirow[t]{2}{*}{ [\%] } & Female & 75 & 36 & $0.3^{\mathrm{aC}}$ & 0.3 & $0.6^{\mathrm{aC}}$ & 0.2 & $2.1^{\mathrm{bB}}$ & 0.2 & $2.9^{\mathrm{bAB}}$ & 0.3 & $4.2^{\mathrm{bA}}$ & 0.4 \\
\hline & Female & 120 & 28 & $0.3^{\mathrm{aC}}$ & 0.2 & $0.8^{\mathrm{aC}}$ & 0.2 & $2.6^{\mathrm{bB}}$ & 0.2 & $4.0^{\mathrm{bA}}$ & 0.2 & $4.4^{\mathrm{bA}}$ & 0.2 \\
\hline
\end{tabular}


The cytological course of events, retraced by the study of hematoxylin-eosin stained histological sections, is documented in Table 2. Due to the low number of fish per group (average 3.4, range 2 to 6) the data appear somewhat erratic, however, the sequence of events is clearly discernible. Five oocyte stages [Selman, and Wallace, 1986] were discernible: chromatin-nucleolus stage, peri-nucleolus stage, cortical alveolus stage, vitellogenic stage and mature oocytes. In ovaries recovered from immature fish of $90 \mathrm{dpf}$, the majority of the oocytes were in the peri-nuclear phase. Between 120 and $180 \mathrm{dpf}$ in both treatment groups a gradual shift toward more advanced oocyte stages was observed, however, the largest proportion of oocytes had remained in the peri-nuclear stage. At 210 dpf approximately one third of the oocytes had reached the vitellogenic stage (Figure 2). A certain proportion of chromatin-nucleolus and peri-nucleolus stages were present throughout the maturation process (Figure 3).

The cortical alveolus stage made its first appearance at 120 dpf (Figure 4). In a few individuals at age $150 \mathrm{dpf}$ a small proportion of oocytes in both treatment and control group had arrived at an advanced stage of development (Figure 5). 
Table 2. Least square means and standard deviations of the proportion of developmental stages of oocytes (\%) at various stages of sexual development in Nile tilapia exposed to elevated temperature $\left(36^{\circ} \mathrm{C}\right)$ from 10 to $20 \mathrm{dpf}$ vs. untreated control females

\begin{tabular}{|c|c|c|c|c|c|c|c|c|c|c|c|}
\hline \multirow{3}{*}{ Oocyte stage } & \multirow{3}{*}{$\begin{array}{l}\text { Temperature } \\
\text { treatment }\left[{ }^{\circ} \mathrm{C}\right]\end{array}$} & \multicolumn{10}{|c|}{ Age [dpf] } \\
\hline & & \multicolumn{2}{|c|}{90} & \multicolumn{2}{|c|}{120} & \multicolumn{2}{|c|}{150} & \multicolumn{2}{|c|}{180} & \multicolumn{2}{|c|}{210} \\
\hline & & Mean & SD & Mean & SD & Mean & SD & Mean & SD & Mean & SD \\
\hline \multirow[t]{2}{*}{ Chromatin nucleolar } & 36 & $5.4^{\mathrm{a} D C}$ & 0.3 & $1.9^{\mathrm{bD}}$ & 0.2 & $8.0^{\mathrm{bB}}$ & 0.3 & $0.8^{\mathrm{bD}}$ & 0.1 & $5.9^{\mathrm{bB}}$ & 0.8 \\
\hline & 28 & $5.9^{\mathrm{aC}}$ & 0.4 & $4.8^{\mathrm{aC}}$ & 0.2 & $2.3^{\mathrm{aC}}$ & 0.2 & $2.1^{\mathrm{aC}}$ & 0.2 & $8.5^{\text {a A }}$ & 0.6 \\
\hline \multirow[t]{2}{*}{ Peri-nucleolar } & 36 & $94.5^{\text {a B }}$ & 0.3 & $97.9^{\mathrm{b} A}$ & 0.3 & $88.3^{\mathrm{aC}}$ & 0.3 & $82.0^{\mathrm{bC}}$ & 0.5 & $45.9^{\mathrm{a} E}$ & 1.2 \\
\hline & 28 & $94.0^{\text {a B }}$ & 0.2 & $94.1^{\text {a B }}$ & 0.4 & $90.6^{\mathrm{aC}}$ & 0.3 & $77.6^{\text {a D }}$ & 0.5 & $54.3^{\mathrm{a} E}$ & 0.8 \\
\hline \multirow[t]{2}{*}{ Cortical alveolar } & 36 & 0 & 0 & $0.08^{\mathrm{aA}}$ & 0.1 & $2.5^{\mathrm{aA}}$ & 0.0 & $3.1^{\text {a A }}$ & 0.1 & $6.2^{\mathrm{aA}}$ & 0.0 \\
\hline & 28 & 0 & 0 & $1.0^{\mathrm{aA}}$ & 0.2 & $2.5^{\mathrm{aA}}$ & 0.0 & $2.4^{\mathrm{a} \mathrm{A}}$ & 0.1 & $5.6^{\mathrm{aA}}$ & 0.0 \\
\hline \multirow[t]{2}{*}{ Vitellogenic } & 36 & 0 & 0 & 0 & 0 & $0.8^{\mathrm{aF}}$ & 0.1 & $13.6^{\mathrm{aD}}$ & 0.1 & $37.8^{\text {a B }}$ & 0.3 \\
\hline & 28 & 0 & 0 & 0 & 0 & $4.4^{\mathrm{bE}}$ & 0.3 & $16.3^{\mathrm{bC}}$ & 0.1 & $26.7^{\mathrm{b} A}$ & 0.3 \\
\hline \multirow[t]{2}{*}{ Mature } & 36 & 0 & 0 & 0 & 0 & $0.1^{\mathrm{aC}}$ & 0.0 & $0.3^{\mathrm{a} \mathrm{B}}$ & 0.0 & $3.9^{\mathrm{a} \mathrm{A}}$ & 0.3 \\
\hline & 28 & 0 & 0 & 0 & 0 & $0.5^{\mathrm{bC}}$ & 0.0 & $1.3^{\mathrm{b} \mathrm{B}}$ & 0.1 & $4.6^{\mathrm{aA}}$ & 0.3 \\
\hline
\end{tabular}

$\overline{\mathrm{acc}}$ Within columns means with different superscripts differ $(\mathrm{P} \leq 0.05) .{ }^{\mathrm{ABC}}$ Within rows means with different superscripts differ $(\mathrm{P}<0.05)$. 
Figure 2. Proportion (\%) of ovaries macro-morphologically classified as immature, maturing, mature, ripening or ripe of generation allfemale tilapia temperature-treated (top) or not (bottom)

$36^{\circ} \mathrm{C}$

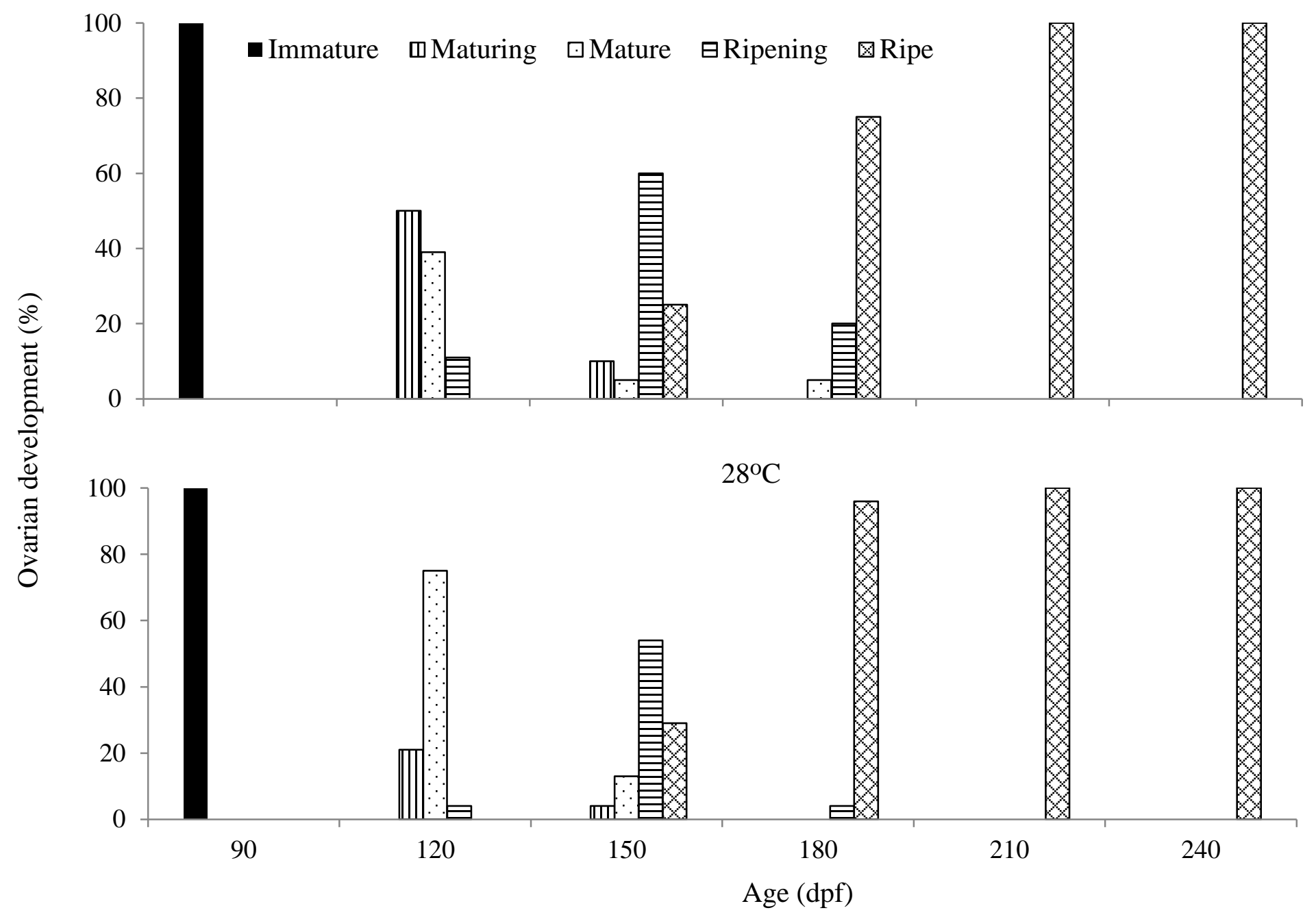


Figure 3. Photomicrograph of the ovarian structures $90 \mathrm{dpf}$ fish of control (A) and temperature-treated group (B). The composition of the cells is similar amongst anterior area (a), middle area (b), and posterior area (c) of the gonads of both groups. The perinucleolus phase oocytes dominate the ovarian structures. Oc: ovarian cavity, Bv: blood vessel, ovarian wall (arrow). HE stains. Bars: $50 \mu \mathrm{m}$

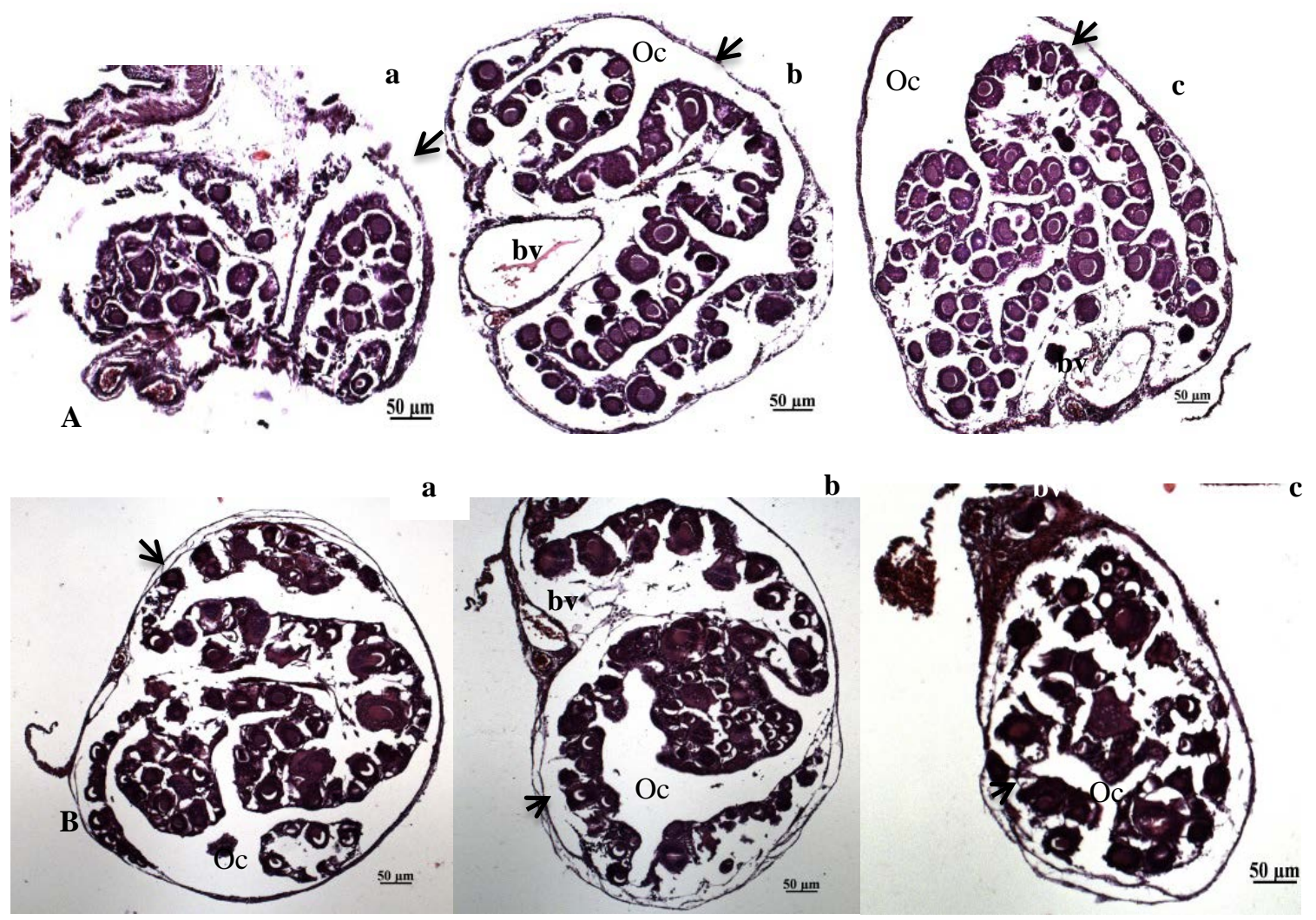


Figure 4. Photomicrograph of the ovarian structures of $120 \mathrm{dpf}$ of control (A) and temperature-treated (B) contain cortical alveolus stage oocyte (asterisk). Oc: ovarian cavity; Bv: blood vessel. HE stains. Bars $=50 \mu \mathrm{m}$.
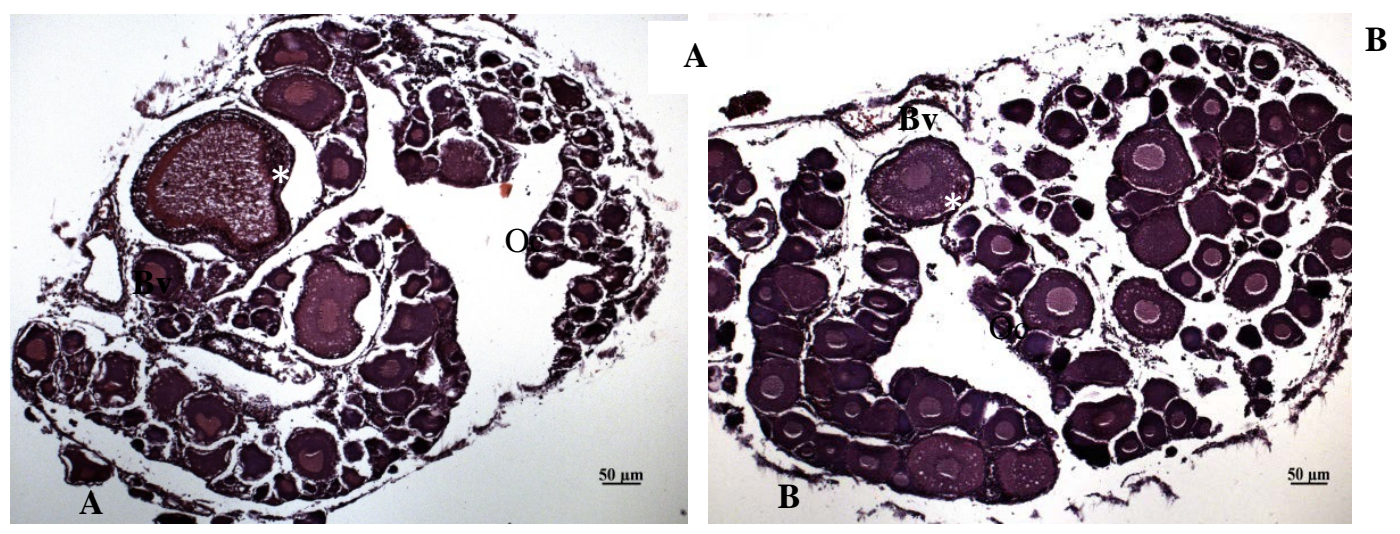

Figure 5. Photomicrograph of the ovarian structures of $150 \mathrm{dpf}$ of control (A) showing the mature ovarian features; and temperature-treated (B) shows the mature ovarian features with the different composition of oocytes stages. Oc: ovarian cavity. HE stains. Bars $=200$ $\mu \mathrm{m}(\mathrm{A}) ; 100 \mu \mathrm{m}(\mathrm{B})$.
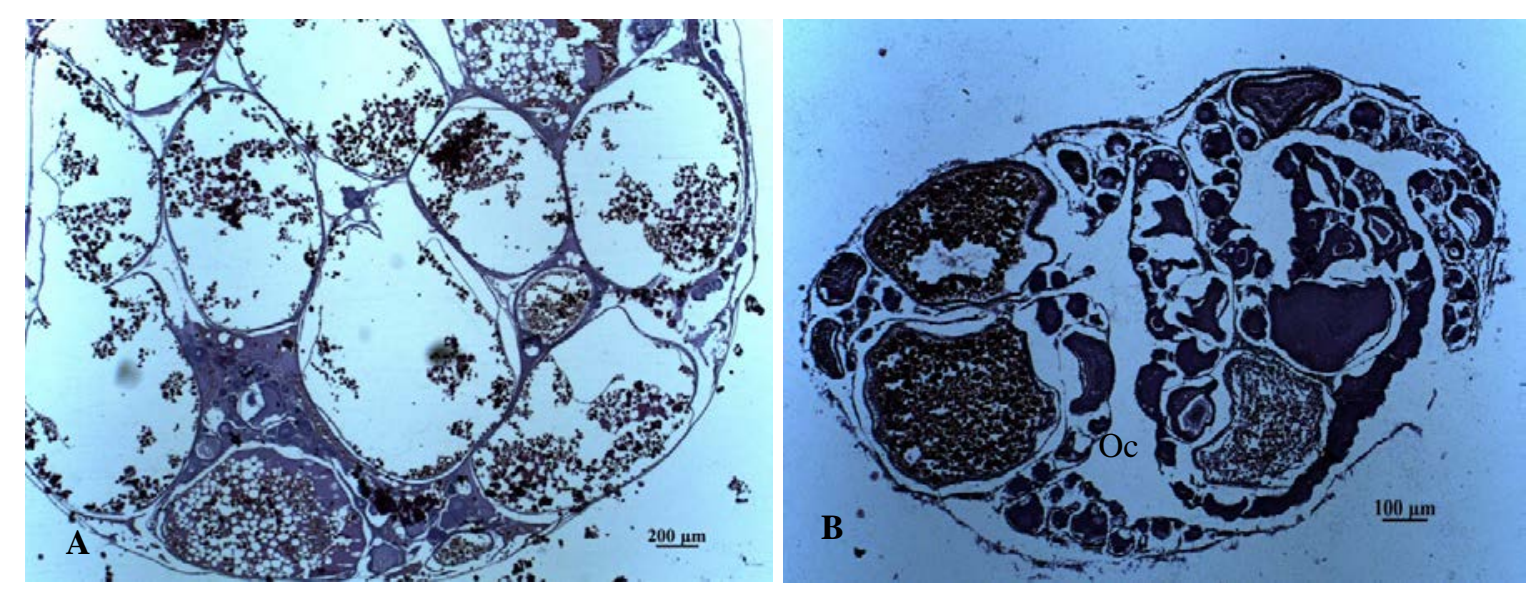
Figure 6. Photomicrograph of the ovarian structures of $180 \mathrm{dpf}$ of control (A) showing mature oocyte (Mo) with germinal vesicle (asterisk) and temperature-treated contain vitellogenic oocyte (v) with germinal vesicle (asterisk) (B). Oc: ovarian cavity, ovarian lamellae wall (arrowhead). HE stains. Bars = $100 \mu \mathrm{m}$ (A); $50 \mu \mathrm{m}$ (B).
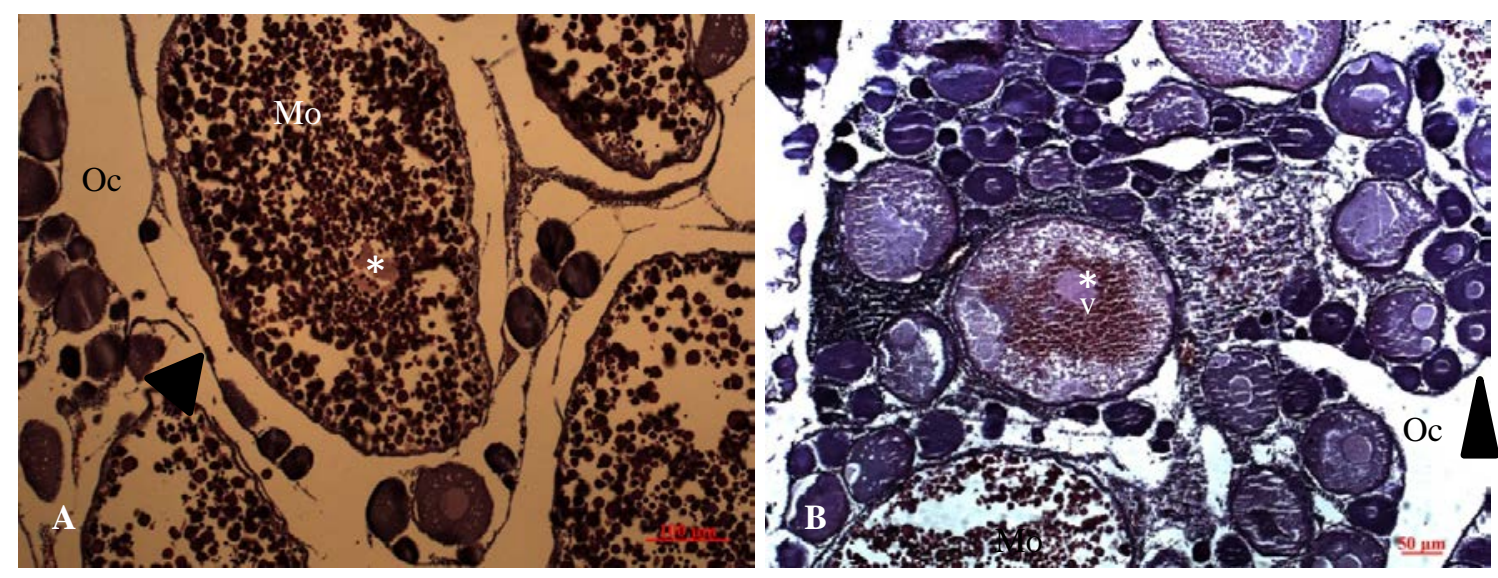

\subsection{Discussion}

In tilapia, differentiation of the gonads into either testes or ovaries with their characteristic morphology takes place at about day 15 to day 30 after fertilization [Yoshikawa, and Oguri, 1978]. Sex reversal by means of temperature treatment during that phase has been carried out before [Baroiller et al., 1995; Tessema et al., 2006]. However, as yet, little is known about the macro- and micro-morphological appearance of the gonads of nonmasculinized females after the temperature treatment. In the present study elevated temperature of $36^{\circ} \mathrm{C}$ from 10 to $20 \mathrm{dpf}$ was applied to induce masculinization of genetically female (XX) individuals. The genetically all-female population was derived from crosses between normal females and a temperature-sex reversed male from a line selected for high temperature-responsiveness ( $>90 \%$ males after $36^{\circ} \mathrm{C}$ treatment from 10 to 20 dpf) [Wessels, and Hoerstgen-Schwark, 2007, 2011]. Here a male percentage of 37\% was found in the temperature-treatment group. In contrast no males were observed in the control group. This result is in accordance with Tessema et al. [2006] and Baroiller et al. 
[1995] who reported that elevated temperature $\left(>34{ }^{\circ} \mathrm{C}\right)$ affects masculinization rate. Wessels and Hoerstgen-Schwark [2011] reported sex ratios of 93\% and 50\% after a threegeneration selection experiment for high and low temperature sensitivity, respectively. In contrast to the present study the authors used mixed sex families (XX/XY). Therefore the male ratios in the present study, which used temperature-induced pseudomales as sires, were significantly lower. However, treatment of mixed-sex populations likely results in higher male ratios, as $\sim 50 \%$ of observed males are genetic males (XY). Depending on temperature-responsiveness of the dam and sire a share of up to $~ 50 \%$ of the remaining XX-individuals will be masculinized, thus leading to sex ratios of up to $100 \%$ males. Distinct male ratios are frequently observed, as sex ratio in Nile tilapia populations is affected by several factors. Sex determination in Nile tilapia involves major and minor genetic as well as exogenous factors such as temperature. Wessels and Hörstgen-Schwark [2007, 2011] reported that the temperature-responsiveness differs amongst families in Nile tilapia and is a heritable trait. Recent studies using genetic markers revealed that genetic markers on LG 1, LG20 and 23 contribute to sex determination [Palaiokostas et al., 2013; Gammerdinger et al., 2014; Wessels et al., 2014]. At least the QTL on LG20 and LG23 are involved in temperature-dependent sex [Palaiokostas et al., 2015; Lühmann et al., 2012; Wessels et al., 2014].

The somatic growth pattern observed in the present study agrees with findings by Magdeldin et al. [2007]. There was a slight tendency toward an enhanced growth rate in temperature-treated females as compared to untreated females. Also, with regard to the GSI an age-related pattern of development was observed, however, contrary to body mass and length, from age 180 dpf onward the GSI was higher in controls than in the nonmasculinized temperature-treated females. The difference was slight. It is open to conjecture whether it has functional relevance. The fact that, with approaching puberty, the GSI of females exceeds that of phenotypic males is not surprising, as in mature tilapia 
testes are smaller than ovaries [Welcomme, 1967; Peters, 1971]. During sex differentiation D’Cotta et al. [2001] observed prominent aromatase gene expression in the gonads of genetic females, concomitant with high levels of estradiol-17 $\beta$. In gonads of males and temperature-masculinized females, much lower levels were found. Furthermore, aromatase levels in brain tissue of females were found to be lower than in genetic males and masculinized females. It is known that elevated water temperature will repress expression of the enzyme aromatase [D’Cotta et al., 2001] which is responsible for the conversion of testosterone to estrogens (Kobayashi et al., 2013). Since estrogens are involved in ovarian differentiation [Guiguen et al., 1999], inhibition of aromatase will result in an accumulation of testosterone and, as a consequence, effectuate masculinization.

As described for Fundulus heteroclitus by Wallace and Selman [1981], early oocyte development comprises pre-vitellogenic chromatin nucleolus, perinucleolus and cortical alveolus stages, and is followed up by the vitellogenic stage of rapid accumulation of vitellogenin which is synthesized in the liver and incorporated into the ova by micropinocytosis. In the course of the transformation of oogonia to oocytes, according to Selman and Wallace [1986] chromatin nucleolus and perinucleolus phase belong to the primary growth stage. At that stage the diameter of the ovarian follicles ranges from 8 to $175 \mu \mathrm{m}$. At the cortical alveolus stage the diameter increases to 175 to $550 \mu \mathrm{m}$, followed by the vitellogenic stage of $0.55 \mathrm{~mm}$ to $1.35 \mathrm{~mm}$ and, at the mature oocyte stage, to $1.35 \mathrm{~mm}$ and more.

In the present study, at 90 dpf the only prevalent stages were the chromatin nucleolus and perinucleolus stage, indicating that in both the control and the temperature-treatment group the ovary had entered the phase of primary growth. These stages were present irrespective of age, indicating that primary growth was perpetuated throughout all stages of ovarian maturation. In female teleosts, unlike higher vertebrates, ovaries retain a stock of undifferentiated oogonia that are renewed by mitotic divisions throughout life. Some of the 
oogonia enter into meiotic division but remain arrested in prophase of meiosis I. The maturing oocytes increase in size and get surrounded by cells of somatic origin: an inner monolayer of granulosa cells in direct contact with the zona radiata and an outer theca externa Kraft $\quad$ Kon and In temperature-treated fish, at most stages, ovaries had a significantly reduced proportion of oocytes in the chromatin nucleolus phase. Generally, with increasing age, fewer oocytes are in the primary growth phase due a shift towards more advanced developmental stages (cortical alveolus, vitellogenic, mature oocyte).

Investigation of the cytological course of events led to the conclusion that, on the basis of the available material it appears unlikely that the temperature treatment exerted a significant effect on gonadal function in non-masculinized female tilapia. Temperature treatment caused enhanced somatic growth. There was a non-significant GSI to be adversely affected by temperature treatment, though there was a slightly tendency that control females possessed higher GSI than non-masculinized temperature-treated females. Implications for the fitness of temperature-treated females should be elucidated in future studies.

\section{Acknowledgements}

We gratefully acknowledge Berti Manshausen at the Division of Anatomy of Goettingen University Medical School for technical assistance with the histological processing of samples.

\subsection{References}

Afonso LO, Wassermann GJ, Terezinha de Oliveira R: Sex reversal in Nile tilapia (Oreochromis niloticus) using a nonsteroidal aromatase inhibitor. J Exp. Zool. 290:177-181 (2001). 
Alvarenga ER de, França LR de: Effects of different temperatures on testis structure and function, with emphasis on somatic cells, in sexually mature Nile Tilapias (Oreochromis niloticus). Biol. Reprod. 80:537-544 (2009).

Babiker MM, Ibrahim H: Studies on the biology of reproduction in the cichIid Tilapia nilotica (L.): gonadal maturation and fecundity. J. Fish Biol. 14:437-448 (1979).

Baroiller J-F, Chourrout D, Fostier A, Jalabert B: Temperature and sex chromosomes govern sex ratios of the mouthbrooding Cichlid fish (Oreochromis niloticus). J. Exp. Zool. 273:216-223 (1995).

Baroiller JF, D’Cotta H, Bezault E, Wessels S, Hoerstgen-Schwark G: Tilapia sex determination: Where temperature and genetics meet. Comp. Biochem. Physiol. - A Mol. Integr. Physiol. 153:30-38 (2009).

Baroiller JF, D’Cotta H: Environment and sex determination in farmed fish, in : Comparative Biochemistry and Physiology - C Toxicology and Pharmacology (2001), pp 399-409.

Bhandari RK, Nakamura M, Kobayashi T, Nagahama Y: Suppression of steroidogenic enzyme expression during androgen-induced sex reversal in Nile tilapia (Oreochromis niloticus). Gen. Comp. Endocrinol. 145:20-24 (2006).

Braat AK, Van De Water S, Goos H, Bogerd J, Zivkovic D: Vasa protein expression and localization in the zebrafish. Mech. Dev. 95:271-274 (2000).

Coward K, Bromage NR: Reproductive physiology of female tilapia broodstock. Rev. Fish. Biol. Fish 10:1-25 (2000). 
D’Cotta H, Fostier a, Guiguen Y, Govoroun M, Baroiller JF: Aromatase plays a key role during normal and temperature- induced sex differentiation of Tilapia Oreochromis niloticus. Mol. Reprod. Dev. 59:265-276 (2001).

De Graaf GJ, Galemoni F, Huisman EA: Reproductive biology of pond reared Nile tilapia, Oreochromis niloticus L. Aquac. Res. 30:25-33 (1999).

Devlin RH, Nagahama Y: Sex determination and sex differentiation in fish: An overview of genetic, physiological, and environmental influences. Aquaculture 208:191-364 (2002).

Gammerdinger WJ, Conte M a, Acquah E a, Roberts RB, Kocher TD: Structure and decay of a proto-Y region in Tilapia, Oreochromis niloticus. BMC Genomics 15:975 (2014).

Getinet, G. Tsadik (Ethiopian Institute of Agricultural Research NAC: Effects of Maternal Age on Fecundity, Spawning Interval, and Egg Quality of Nile tilapia, Oreochromis niloticus (L.). J. World Aquac. Soc. 39:671-677 (2008).

Grier $\mathrm{H}$ : Ovarian germinal epithelium and folliculogenesis in the common snook, Centropomus undecimalis (Teleostei: Centropomidae). J. Morphol. 243:265-281 (2000).

Grier HJ, Uribe MC, Parenti LR: Germinal epithelium, folliculogenesis, and postovulatory follicles in ovaries of rainbow trout, Oncorhynchus mykiss (Walbaum, 1792) (Teleostei, Protacanthopterygii, Salmoniformes). J. Morphol. 268:293-310 (2007).

Guiguen Y, Baroiller JF, Ricordel MJ, Iseki K, McMeel OM, Martin SAM, et al.: Involvement of estrogens in the process of sex differentiation in two fish species: 
The rainbow trout (Oncorhynchus mykiss) and a tilapia (Oreochromis niloticus). Mol. Reprod. Dev. 54:154-162 (1999).

Gustafson EA, Wessel GM: Vasa genes: Emerging roles in the germ line and in multipotent cells. BioEssays 32:626-637 (2010).

Hanna CB, Hennebold JD: Ovarian germline stem cells: An unlimited source of oocytes? Fertil Steril 101:20-30 (2014).

Hattori RS, Gould RJ, Fujioka T, Saito T, Kurita J, Strüssmann CA, et al.: Temperaturedependent sex determination in Hd-rR medaka Oryzias latipes: Gender sensitivity, thermal threshold, critical period, and DMRT1 expression profile. Sex. Dev. 1:138146 (2007).

Hayashi Y, Kobira H, Yamaguchi T, Shiraishi E, Yazawa T, Hirai T, et al.: High temperature causes masculinization of genetically female medaka by elevation of cortisol. Mol. Reprod. Dev 77:679-686 (2010).

TreasuresHolliday JWTFGT: Some aspects of the reproductive biology of perch Perca fluviatilis L. A histological description of the reproductive cycle. J Fish Biol 18:359-376 (1981).

Ijiri S, Kaneko H, Kobayashi T, Wang DS, Sakai F, Paul-Prasanth B, et al.: Sexual dimorphic expression of genes in gonads during early differentiation of a teleost fish, the Nile tilapia Oreochromis niloticus. Biol Reprod 78:333-341 (2008).

Ito LS, Takahashi C, Yamashita M, StrÃ¹/4ssmann CA: Warm Water Induces Apoptosis, Gonadal Degeneration, and Germ Cell Loss in Subadult Pejerrey Odontesthes bonariensis (Pisces, Atheriniformes). Physiol Biochem Zool 81:762-774 (2008).

Kelman Z: PCNA : structure, functions and interactions (1997). 
Knaut H, Pelegri F, Bohmann K, Schwarz H, Nüsslein-Volhard C: Zebrafish vasa RNA but not its protein is a component of the germ plasm and segregates asymmetrically before germline specification. J Cell Biol 149:875-888 (2000).

Knaut H, Steinbeisser H, Schwarz H, Nüsslein-Volhard C: An evolutionary conserved region in the vasa 3'UTR targets RNA translation to the germ cells in the zebrafish. Curr Biol 12:454-466 (2002).

Kobayashi T, Ishibashi R, Yamamoto S, Otani S, Ueno K, Murata O: Gonadal morphogenesis and sex differentiation in cultured chub mackerel, Scomber japonicus. Aquac Res 42:230-239 (2011).

Kobayashi T, Kajiura-Kobayashi H, Nagahama Y: Differential expression of vasa homologue gene in the germ cells during oogenesis and spermatogenesis in a teleost fish, tilapia, Oreochromis niloticus. Mech Dev 99:139-142 (2000).

Kobayashi T, Kajiura-Kobayashi H, Nagahama Y: Germ cells during gonadal sex differentiation in the teleost. Fish Physiol Biochem 28:157 (2003).

Kobayashi T: In vitro germ cell differentiation during sex differentiation in a teleost fish. Int J Dev Biol 54:105-112 (2010).

Kobayashi Y, Nagahama Y, Nakamura M: Diversity and plasticity of sex determination and differentiation in fishes. Sex Dev 7:115-125 (2012).

Kronert U, Hörstgen-Schwark G, Langholz HJ: Prospects of selecting for late maturity in tilapia (Oreochromis niloticus). I. Family studies under laboratory conditions. Aquaculture 77:113-121 (1989). 
Lacerda SMSN, Costa GMJ, Campos-Junior PHA, Segatelli TM, Yazawa R, Takeuchi Y, et al.: Germ cell transplantation as a potential biotechnological approach to fish reproduction. Fish Physiol Biochem 39:3-11 (2013).

Lee KH, Yamaguchi A, Rashid H, Kadomura K, Yasumoto S, Matsuyama M: Germ cell degeneration in high-temperature treated pufferfish, Takifugu rubripes. Sex Dev 3:225-232 (2009).

Littell RC, Milliken GA, Stroup WW, Wolfinger RD: SAS system for mixed models. (1996). DOI: 10.1017/CBO9781107415324.004

Lühmann LM, Knorr C, Hörstgen-Schwark G, Wessels S: First evidence for familyspecific QTL for temperature-dependent sex reversal in Nile tilapia (Oreochromis niloticus). Sex Dev 6:247-256 (2012).

Magdeldin S, Uchida K, Hirano T, Grau EG, Abdelfattah A, Nozaki M: Effects of environmental salinity on somatic growth and growth hormone/insulin-like growth factor-I axis in juvenile tilapia Oreochromis mossambicus. Fish Sci 73:1025-1034 (2007).

Nagasawa K, Fernandes JMO, Yoshizaki G, Miwa M, Babiak I: Identification and migration of primordial germ cells in Atlantic salmon, Salmo salar: Characterization of Vasa, Dead End, and Lymphocyte antigen 75 genes. Mol Reprod Dev 80:118131 (2013).

Nakamura M, Bhandari RK, Higa M: The role estrogens play in sex differentiation and sex changes of fish. Fish Physiol Biochem 28:113-117 (2003).

Nakamura M, Kobayashi T, Chang XT, Nagahama Y: Gonadal sex differentiation in teleost fish. J Exp Zool 281:362-372 (1998). 
Nakamura M, Takahashi H: Sex differentiation in Tilapia mossambica, with special regard to the time of estrogen treatment effective in inducing complete feminization of genetic males [Internet]. Bull Fac Fish Hokkaido Univ 24:1-13 (1973).

Nakamura S, Kobayashi K, Nishimura T, Higashijima S -i., Tanaka M: Identification of Germline Stem Cells in the Ovary of the Teleost Medaka. Science (80- ) 328:15611563 (2010).

Nakamura S, Kobayashi K, Nishimura T, Tanaka M: Ovarian germline stem cells in the teleost fish, medaka (Oryzias latipes). Int J Biol Sci 7:403-409 (2011).

Nakamura S: Identification of Germline Stem Cells 1561 (2010). DOI: 10.1126/science.1185473

Okutsu T, Suzuki K, Takeuchi Y, Takeuchi T, Yoshizaki G: Testicular germ cells can colonize sexually undifferentiated embryonic gonad and produce functional eggs in fish. Proc Natl Acad Sci U S A 103:2725-2729 (2006).

Oldorf W, Kronert U, Balarin J, Haller R, Hörstgen-Schwark G, Langholz HJ: Prospects of selecting for late maturity in tilapia (Oreochromis niloticus). II. Strain comparisons under laboratory and field conditions. Aquaculture 77:123-133 (1989).

Olsen LC, Aasland R, Fjose A: A vasa-like gene in zebrafish identifies putative primordial germ cells. Mech Dev 66:95-105 (1997).

Palaiokostas C, Bekaert M, Khan MGQ, Taggart JB, Gharbi K, McAndrew BJ, et al.: A novel sex-determining QTL in Nile tilapia (Oreochromis niloticus). BMC Genomics $16: 171$ (2015). 
Palaiokostas C, Bekaert M, Khan MGQ, Taggart JB, Gharbi K, McAndrew BJ, et al.: Mapping and Validation of the Major Sex-Determining Region in Nile Tilapia (Oreochromis niloticus L.) Using RAD Sequencing. PLoS One 8:1-9 (2013).

Paunesku T, Mittal S, Protić M, Oryhon J, Korolev S V, Joachimiak A, et al.: Proliferating cell nuclear antigen (PCNA): ringmaster of the genome. Int J Radiat Biol 77:10071021 (2001).

Peters, H.M. 1971. Testis weight in Tilapia (Pisces: Cichlidae). Copeia 1 : 13-17.

Pfennig F, Kurth T, Meissner S, Standke A, Hoppe M, Zieschang F, et al.: The social status of the male Nile tilapia (Oreochromis niloticus) influences testis structure and gene expression. Reproduction 143:71-84 (2012).

Poonlaphdecha S, Pepey E, Huang SH, Canonne M, Soler L, Mortaji S, et al.: Elevated amh gene expression in the brain of male tilapia (Oreochromis niloticus) during testis differentiation. Sex Dev 5:33-47 (2011).

Raz E: Primordial germ-cell development: the zebrafish perspective. Nat Rev Genet 4:690-700 (2003).

Rougeot C, Kanfitine SY, Prignon C, Gennotte V, Mélard C: Early sex reversal during embryonic development in the Nile tilapia. Cybium 32:104-105 (2008).

Saito D, Morinaga C, Aoki Y, Nakamura S, Mitani H, Furutani-Seiki M, et al.: Proliferation of germ cells during gonadal sex differentiation in medaka: Insights from germ cell-depleted mutant zenzai. Dev Biol 310:280-290 (2007).

Selim KM, Shinomiya A, Otake H, Hamaguchi S, Sakaizumi M: Effects of high temperature on sex differentiation and germ cell population in medaka, Oryzias latipes. Aquaculture 289:340-349 (2009). 
Selman K, Wallace RA: Gametogenesis in Fundulus heteroclitus. Integr Comp Biol 26:173-192 (1986).

Sengoku T, Nureki O, Nakamura A, Kobayashi S, Yokoyama S: Structural Basis for RNA Unwinding by the DEAD-Box Protein Drosophila Vasa. Cell 125:287-300 (2006).

Shirak A, Seroussi E, Cnaani A, Howe AE, Domokhovsky R, Zilberman N, et al.: Amh and Dmrta2 genes map to tilapia (Oreochromis spp.) linkage group 23 within quantitative trait locus regions for sex determination. Genetics 174:1573-1581 (2006).

Siegfried KR, Nüsslein-Volhard C: Germ line control of female sex determination in zebrafish. Dev Biol 324:277-287 (2008).

Slanchev K: Molecular mechanisms governing germ line development in zebrafish and the role of this lineage in sexual differentiation [Internet]. . Dev Biol (2005). Available from: http://webdoc.sub.gwdg.de/diss/2006/slanchev/

Spradling A, Fuller MT, Braun RE, Yoshida S: Germline stem cells. Cold Spring Harb Perspect Biol 3:a002642 (2011).

Strome S, Updike D: Specifying and protecting germ cell fate. Nat Rev Mol Cell Biol 16:406-16 (2015).

Strüssmann CA, Nakamura M: Morphology, endocrinology, and environmental modulation of gonadal sex differentiation in teleost fishes. Fish Physiol Biochem 26:13-29 (2002).

Sun LN, Jiang XL, Xie QP, Yuan J, Huang BF, Tao WJ, et al.: Transdifferentiation of differentiated ovary into functional testis by long-term treatment of aromatase inhibitor in Nile tilapia. Endocrinology 155:1476-1488 (2014). 
Tessema M, Müller-Belecke A, Hörstgen-Schwark G: Effect of rearing temperatures on the sex ratios of Oreochromis niloticus populations. Aquaculture 258:270-277 (2006).

Uchida D, Yamashita M, Kitano T, Iguchi T: An aromatase inhibitor or high water temperature induce oocyte apoptosis and depletion of P450 aromatase activity in the gonads of genetic female zebrafish during sex-reversal. Comp Biochem Physiol - A Mol Integr Physiol 137:11-20 (2004).

von Kraft, A. and H.M., Peters. 1963. Vergleichende studien hber die oogenese in der gattung tilapia (cichlidae, teleostei). Zellforsch. Mikrosk. Anat. 61: 434-485.

Wallace RA, Selman K: Cellular and dynamic aspects of Oocyte growth in Teleosts. Integr Comp Biol 21:325-343 (1981).

Wang DS, Zhou LY, Kobayashi T, Matsuda M, Shibata Y, Sakai F, et al.: Doublesex- and Mab-3-related transcription factor-1 repression of aromatase transcription, a possible mechanism favoring the male pathway in Tilapia. Endocrinology 151:1331-1340 (2010).

Wessels S, Hoerstgen-Schwark G: Selection experiments to increase the proportion of males in Nile tilapia (Oreochromis niloticus) by means of temperature treatment. Aquaculture 272:S80-S87 (2007).

Wessels S, Hoerstgen-Schwark G: Temperature dependent sex ratios in selected lines and crosses with a YY-male in Nile tilapia (Oreochromis niloticus). Aquaculture 318:79-84 (2011). 
Wessels S, Hörstgen-Schwark G: Selection experiments to increase the proportion of males in Nile tilapia (Oreochromis niloticus) by means of temperature treatment. Aquaculture 272 (2007). DOI: 10.1016/j.aquaculture.2007.08.009

Wessels S, Hörstgen-Schwark G: Temperature dependent sex ratios in selected lines and crosses with a YY-male in Nile tilapia (Oreochromis niloticus). Aquaculture 318:79-84 (2011).

Wessels S, Sharifi RA, Luehmann LM, Rueangsri S, Krause I, Pach S, et al.: Allelic variant in the anti-müllerian hormone gene leads to autosomal and temperaturedependent sex reversal in a selected nile tilapia line. PLoS One 9 (2014). DOI: 10.1371/journal.pone.0104795

Wildner DD, Grier H, Quagio-Grassiotto I: Female germ cell renewal during the annual reproductive cycle in Ostariophysians fish. Theriogenology 79:709-724 (2013).

Wong T-T, Saito T, Crodian J, Collodi P: Zebrafish germline chimeras produced by transplantation of ovarian germ cells into sterile host larvae. Biol Reprod 84:11901197 (2011).

Xu H, Lim M, Dwarakanath M, Hong Y: Vasa identifies germ cells and critical stages of oogenesis in the asian seabass. Int J Biol Sci 10:225-235 (2014).

Yoon C, Kawakami K, Hopkins N: Zebrafish vasa homologue RNA is localized to the cleavage planes of 2- and 4-cell-stage embryos and is expressed in the primordial germ cells. [Internet]. . Development 124:3157-65 (1997).

Yoshikawa H, Oguri M: Effects of steroid hormones on the sex differentiation in a cichlid fish, Tilapia zillii. BullJapSocSciFish :Soc-1097 (1978). 
Yoshizaki G, Ichikawa M, Hayashi M, Iwasaki Y, Miwa M, Shikina S, et al.: Sexual plasticity of ovarian germ cells in rainbow trout. Development 137:1227-30 (2010).

Yoshizaki G, Takeuchi Y, Kobayashi T, Ihara S, Takeuchi T: Primordial germ cells: The blueprint for a piscine life. Fish Physiol Biochem 26:3-12 (2002).

Yoshizaki G, Takeuchi Y, Sakatani S, Takeuchi T: Germ cell-specific expression of green fluorescent protein in transgenic rainbow trout under control of the rainbow trout vasa-like gene promoter. Int J Dev Biol 44:323-326 (2000). 


\section{CHAPTER 3}

\section{GERMLINE DEVELOPMENT OF NILE TILAPIA (Oreochromis niloticus) REARED UNDER DIFFERENT TEMPERATURE REGIMES}

Manuscript has been submitted to Sexual Development Journal

Aulidya Nurul Habibah ${ }^{1}$, Frank Pfennig ${ }^{2}$, Joerg Wilting ${ }^{3}$, Wolfgang Holtz ${ }^{1}$, Gabriele Hoerstgen-Schwark ${ }^{1}$ and Stephan Wessels ${ }^{1}$

\footnotetext{
${ }^{1}$ Department of Animal Sciences, Division of Aquaculture and Water Ecology, University of Goettingen, Albrecht Thaer Weg 3, D-37075, Goettingen, Germany

${ }^{2}$ Institute of Zoology, Technische Universität Dresden, D-01062 Dresden, Germany

${ }^{3}$ Institute of Anatomy and Cell Biology, University Medical School Goettingen, Kreuzbergring 36, D-37075 Goettingen, Germany
} 


\subsection{Abstract}

In teleosts, elevated temperature during embryogenesis can act on germline cell development, which in turn plays a role for sexual fate. In Nile tilapia, a species with high temperature-induced masculinization, little is known about the effects of increased temperature on gonadal development in non-masculinized females. The aim of the present work was to investigate the germline of genetically female (XX) Nile tilapia reared at normal $\left(28^{\circ} \mathrm{C}\right)$ or elevated temperature $\left(36^{\circ} \mathrm{C}\right)$ during the critical time of gonadal sex differentiation at 10 to 20 days post fertilization. Non-sex-reversed females were compared to control females to determine persistent effects of temperature on subsequent ovarian development using histological approaches. Germline stem cells were identified using the germline marker Vasa in combination with the proliferation marker PCNA. Vasa- and PCNA-positive germline stem cells were found in ovaries of both high temperature $\left(36^{\circ} \mathrm{C}\right)$ and control females. Thereby, in control and temperature-treated groups ovarian germline stem cells were located at the germinal epithelium of the ovigerous lamellae. Although no detrimental effects of high temperature on gonadal development in female Nile tilapia were observed, implications on the reproductive fitness and adaptive significance of temperature-induced masculinization need to be investigated in greater depth.

Keywords: Nile tilapia, sex determination, temperature, germ line stem cells, Vasa, PCNA 


\subsection{Introduction}

Teleosts belong to a group of vertebrates characterized by sexual bipotency [Nakamura et al., 2003]. Unlike mammals, male and female fish possess proliferating germ cells during their whole lifespan [Wildner et al., 2013]. Furthermore, the germline identity in fish is continuous and is transmitted through the oocyte to the primordial germ cells (PGCs) [Strome, and Updike, 2015]. Germ cells give rise to sperm and eggs, thus passing genetic information on from one generation to the next [Raz, 2003]. Furthermore, PGCs play an important role during sex differentiation, which commences when the proliferating PGCs in the gonadal anlagen reach a particular number [Nakamura et al., 1998]. These cells are known as progenitors of germ cells, which can be either oogonia or spermatogonia [Yoshizaki et al., 2002]. During embryonic development, PGCs are located outside the gonad primordia [Kobayashi et al., 2012; Yoshizaki et al., 2002]. In tilapia, PGCs are located in the area between gut and mesonephric duct and migrate to the gonad via the dorsal mesentery [Devlin, and Nagahama, 2002]. After reaching the gonad, the germ cells divide [Nakamura, and Takahashi, 1973]. In female tilapia, proliferation of germ cells starts at day nine post hatching, whereas in males it occurs between nine and 14 days post hatching (dph) [Kobayashi et al., 2012], i.e. to 19 days post fertilization (dpf). The ovarian cavity forms after the first germ cells enter meiosis and proliferate [Kobayashi et al., 2011; Devlin, and Nagahama, 2002]. In females of Nile tilapia gonadal differentiation is evident at age $20 \mathrm{dph}$, indicated by formation of the ovarian cavity. In contrast, male tilapia gonads differentiate at age $25 \mathrm{dph}$, equivalent to $29 \mathrm{dpf}$, indicated by the formation of efferent ducts [Kobayashi et al., 2012].

The investigation of germ line stem cell development requires useful markers for a clearcut identification [Xu et al., 2014]. As such, Vasa is a well-investigated germ cell marker in the entire animal kingdom [Olsen et al., 1997; Yoshizaki et al., 2000; Yoshizaki et al., 
2002; Gustafson and Wessel, 2010; Nagasawa et al., 2013; Braat et al., 2000; Knaut et al., 2000]. It belongs to the DEAD box protein family [Sengoku et al., 2006], and a strong expression is detectable as soon as during early germ cell development in ovaries and testes. Use of Vasa antibodies as germline marker has proven successful for the identification of pre-meiotic germline cells in Nile tilapia [Pfennig et al., 2012]. In more advanced germ cells, vasa RNA expression is quickly diminished. In the ovaries vasa RNA expression persists until the pre-vitellogenic stage, whereas in the testes, vasa RNA expression is only prominent in spermatogonia [Kobayashi et al., 2000]. Furthermore, Knaut et al. [Knaut et al., 2002] have shown that vasa RNA determines the fate of the germline.

A unique characteristic of the female teleost germline is the capability of proliferating throughout the entire lifespan [Wildner et al., 2013]. The Proliferating Cell Nuclear Antigen (PCNA) is a pertinent marker for germline cell proliferation and mitotically active cells [Kelman, 1997].

Sexual fate in many teleost fish can further be affected by means of external cues [Nakamura et al., 1998]. The extreme plasticity of teleost sex determination and differentiation mechanisms fosters phenotypic sex reversal, as observed in Nile tilapia [Baroiller and D’Cotta, 2001]. In Nile tilapia elevated temperature applied during gonadal differentiation commonly leads to phenotypic masculinization [Baroiller et al., 1995; D’Cotta et al., 2001; Tessema et al., 2006]. Elevated temperature applied during sex differentiation might affect germ cells. In medaka (Oryzias latipes), with male heterogametic sex determination $(\mathrm{XX} / \mathrm{XY})$, temperature elevation to $32-34^{\circ} \mathrm{C}$ from the commencement of sex differentiation (stage $25=2$ days and 2 hours post fertilization) until hatching (stage $39=9$ days post fertilization) induces sex reversal of XX-individuals to pseudomales [Hattori et al., 2007; Selim et al., 2009; Hayashi et al., 2010]. 
According to the authors, high temperatures prevented the proliferation of germ cells and the development of oocytes, thus leading to phenotypic sex reversal. In the puffer fish (Takifugu rubripes), elevated temperature $\left(32^{\circ} \mathrm{C}\right)$ led to gonadal degeneration, resulting in gonads without germ cells [Lee et al., 2009]. Nevertheless, morphological sex differentiation of ovarian structures was maintained [Lee et al., 2009]. Siegfried and Nüsslein-Volhard [2008] demonstrated that the germline is required for ovary or testis development in zebrafish (Danio rerio). The absence of a germline led to testis development and normal male somatic structures in the gonad, indicating that low numbers of PGCs trigger male development of the gonad [Slanchev, 2005; Saito et al., 2007]. Okutsu et al. [2006] transplanted spermatogonial stem cells from adult male rainbow trout (Oncorhynchus mykiss) to newly hatched trout embryos from either sex. Male recipients produced spermatozoa, whereas female recipients had functional eggs in the differentiated gonad. Furthermore, Wong et al. [2011] transplanted adult ovarian germline stem cells isolated from adult zebrafish (Danio rerio) into male recipients, which resulted in proliferation and differentiation of functional male germ cells in the recipients. Moreover, Yoshizaki et al. [2010] stated that sexual plasticity is strongest at the time before sexes differentiate. In Nile tilapia, PGC development and differentiation has not been studied in detail. Conceivably, PCGs are sensitive to high water temperature, as well. At elevated temperature germ cell apoptosis might lead to the development of male somatic tissues [Alvarenga and França, 2009].

There is ample information about temperature-induced pseudomales; however a lack in knowledge concerning the ovarian germline in tilapia exposed to different temperature regimes. Furthermore, implications of temperature effects on reproductive fitness and adaptive significance of temperature-dependent sex reversal have not been investigated in depth in female tilapia. 
Therefore, the present study is aimed at investigating germline stem cell development of genetically all-female tilapia subjected to temperature treatment during gonadal differentiation, using histologic and immunohistochemic techniques.

\subsection{Material and Methods}

\subsubsection{Experimental design, fish maintenance and sampling}

All experiments with live fish were carried out in the warm water recirculation unit of the Division of Aquaculture and Water Ecology of the Department of Animal Sciences, Goettingen University. Parental fish were kept at $28^{\circ} \mathrm{C}$ in a warm water recirculation system. Genetic females were hand-stripped upon identification of reproductive behaviour (swollen urogenital papilla and aggressive behaviour). Sperm from a temperature-treated pseudo male (XX) was used to fertilize eggs by way of an artificial fertilization. Thereafter eggs were incubated for 9 days in $2 \mathrm{cl}$ jars with continuous flow of water at $28^{\circ} \mathrm{C}$. On day ten, genetic female $(\mathrm{XX})$ fry were divided into a treatment group at kept at $36^{\circ} \mathrm{C}$ and a control group kept at $28^{\circ} \mathrm{C}$ as practiced by Tessema et al. [2006]. After 10 days of treatment fish were carefully re-acclimatized to $28^{\circ} \mathrm{C}$ and raised to adulthood. Fish were sampled at 60 days-post fertilization (dpf), 90 dpf, 120 dpf, 150 dpf, $180 \mathrm{dpf}$ and $210 \mathrm{dpf}$. Six fish at a time were netted and killed using an overdose of ethylene glycol mono-phenyl ether (Merck, Germany). All procedures were in strict accordance with the recommendations in the Guide for the Care and Use of Laboratory Animals of the German Animal Welfare Act. This study was approved by the Institutional Animal Care and Use Committee of Goettingen University.

In the controls only female fish were found, thus all samples consisted of female gonads. In the treatment group, males and females were found and thus, both ovaries and testes were sampled. 
Fish were dissected and the excised gonads were directly transferred to phosphate-buffered saline. Paraformaldehyde at a concentration of $4 \%$ was used as fixative when applying the Polyfreeze-tissue-freezing-medium-embedding as well as paraffin-embedding. Partially no fixative was used when the Polyfreeze-tissue-freezing-medium-embedding approach was pursued, in order to compare fixative used/not used in the respective group. Gonad samples that were to be paraffin-embedded were fixed in paraformaldehyde (4\%) overnight, dehydrated in increasing concentrations of ethanol (70\%, 80\%, 90\%, 100\%, and $100 \%)$, followed by two xylene baths, and eventually embedding in paraffin. Samples for the Polyfreeze-tissue-freezing-medium-embedded approach were divided up into one group that was fixed in paraformaldehyde (4\%) and one group that was not fixated. Fixation of samples for the Polyfreeze-tissue-freezing-medium-embedding approach took place in paraformaldehyde (4\%), where they were left for 15 minutes at room temperature. They were then rinsed for 5 minutes in phosphate-buffered saline at $\mathrm{pH} 7.3$ at room temperature, followed by submersion in sucrose solution $10 \%$ for 2 hours and sucrose solution 30\% overnight at $4^{\circ} \mathrm{C}$. Samples were then embedded in Polyfreeze tissue freezing medium (Polysciences, Inc., Germany) and adjusted to the respective section orientation. Samples that were not fixated, were directly rinsed with phosphate-buffer-saline solution $\mathrm{pH}$ 7.3, for 5 minutes at room temperature, and then in the same way as fixated samples.

\subsubsection{Sectioning}

Paraffin-embedded samples were sectioned at $7 \mu \mathrm{M}$ with a microtome (Leica Wetzlar, Germany), whereas the Polyfreeze-tissue-freezing-medium-embedded samples were sectioned at $12 \mu \mathrm{M}$ with a cryostat (Leica, Wetzlar, Germany). Samples to be immunostained, samples were either stored at room temperature (paraffin-embedded sections) or at $4{ }^{\circ} \mathrm{C}$ (Polyfreeze-tissue-freezing-medium-embedded). 


\subsubsection{Immunostaining of paraffin-embedded samples}

Sections were successively passed through two xylene baths, decreasing ethanol baths (100\%, 90\%, 80\%, and 70\%), and aquaDes followed by antigen-unmasking in citrate buffer (pH 6) in a micro-wave $(4 \times 5 \mathrm{~min}$. at $600 \mathrm{~W})$. After cooling to room temperature for 20 minutes, samples were transferred from tris-buffered saline/tween $0.1 \%$, $2 \mathrm{x}$ with agitation, into $3 \% \mathrm{H}_{2} \mathrm{O}_{2}$ in methanol (30 min), triple washing in tris-buffered saline/tween $0.1 \%$, and into $1 \%$ BSA in phosphate-buffered saline and the primary antibody: zebrafishVasa 1:100 (rabbit-polyclonal, Knaut et al. 2000) and PCNA 1:100 (mouse-monoclonal, DAKO, Glostrup, Denmark) staining overnight at $4^{\circ} \mathrm{C}$. On the following day, samples were washed three times for 3 minutes in tris-buffered saline/tween $0.1 \%$, incubated with secondary anti-rabbit antibody conjugated with Rhodamine 1:1000 (Jackson Immunoresearch 111-295-003) and anti-mouse-Alexa 488 1:250 (Cell signalling 4408) for 1 hour, and rinsed three times for five minutes each in tris-buffered saline/tween $0.1 \%$. Nuclei were counter-stained with DAPI (1:10.000 from the stock solution $5 \mathrm{mg} / \mathrm{ml})$. Negative control immunostainings were performed by omitting the primary antibody.

\subsubsection{Immunostaining of Polyfreeze-tissue-freezing-medium-embedded samples}

Sections were kept at room temperature for 1 hour before processing. Negative controls for immunostainings were performed by omission of the primary antibody. Blocking of protein binding sites was carried out with $1 \%$ bovine serum albumin for 1 hour, followed by overnight Vasa and PCNA staining as the primary antibodies (see above). After washing twice in $0.1 \mathrm{M}$ K-phosphate-buffer, samples were stained with secondary antibody conjugated with Rhodamine red (Jackson Immuno-research 111-295-003) and Alexa-fluor 488 (Cell signalling 4408) for 1 hour at room temperature followed by counterstaining with DAPI (1:10.000). 
Immunostained sections were kept at $4^{\circ} \mathrm{C}$ until inspection. A fluorescence microscope (AxioImager; Zeiss, Goettingen, Germany) equipped with the Axio Vision software release 4.6.3 SP1 (11-2007) was used for investigation of sections.

\subsection{Results}

In the genetically female control group reared at a constant $28^{\circ} \mathrm{C}$ no males were observed. Of the temperature-treatment group $\left(36^{\circ} \mathrm{C}\right.$ from 10 to $\left.20 \mathrm{dpf}\right) 37 \%$ were males. Histological analysis revealed that all sampled individuals showed complete sex reversal. In temperature-treated fish no intersex structures were observed, neither in ovaries nor in testes. Generally, ovarian structures were more consistently conserved in fixated samples than in samples without fixation. Samples of ovaries for the Polyfreeze-tissue-freezingmedium-embedded approach showed a high degree of shrinkage (Figure 7). Therefore, analysis of the germline was based on evaluation of paraffin-embedded sections only. Germ line stem cells were identified based on the following criteria: detection of a strong Vasa signal in early germ cells; a typical morphology of early germ cells as single cell or within the nest [Nakamura et al., 2011]; typical localization of germline stem cells at the germinal epithelium of the ovigerous lamellae; a characteristic PCNA signal in the nuclei of proliferating germ cells. Ovarian germline stem cells were identified at all sampling times (60 to 210 dpf) in both control and treatment group. Expression of PCNA and Vasa was detected in all ovary sections irrespective of age and treatment. Ovarian germline stem cells were found exclusively in the germinal epithelium of the ovigerous lamellae, both in the control and in the treatment group (Figure 8).

Moreover, ovarian germline stem cells of two distinct types were identified: single, isolated germline stem cells and nested germline stem cells in interconnected clutches (Figure 9), both of which were located in niches. Niches resemble the germinal cradle, a structure containing germline cells, advanced cells and supporting cells. Nakamura et al. 
[2010] defined the germinal cradle as a cluster of early-stage germ cells supported by interwoven threadlike cords of sox $9 b$-expressing somatic cells. The niches were exclusively located in the germinal epithelium of the ovigerous lamellae. Nested germline stem cells as well as single cells were in active proliferation, indicated by PCNA-positive staining. Moreover, single isolated germline stem cells were long and of irregular shape, whereas nested germline stem cells had a round shape.

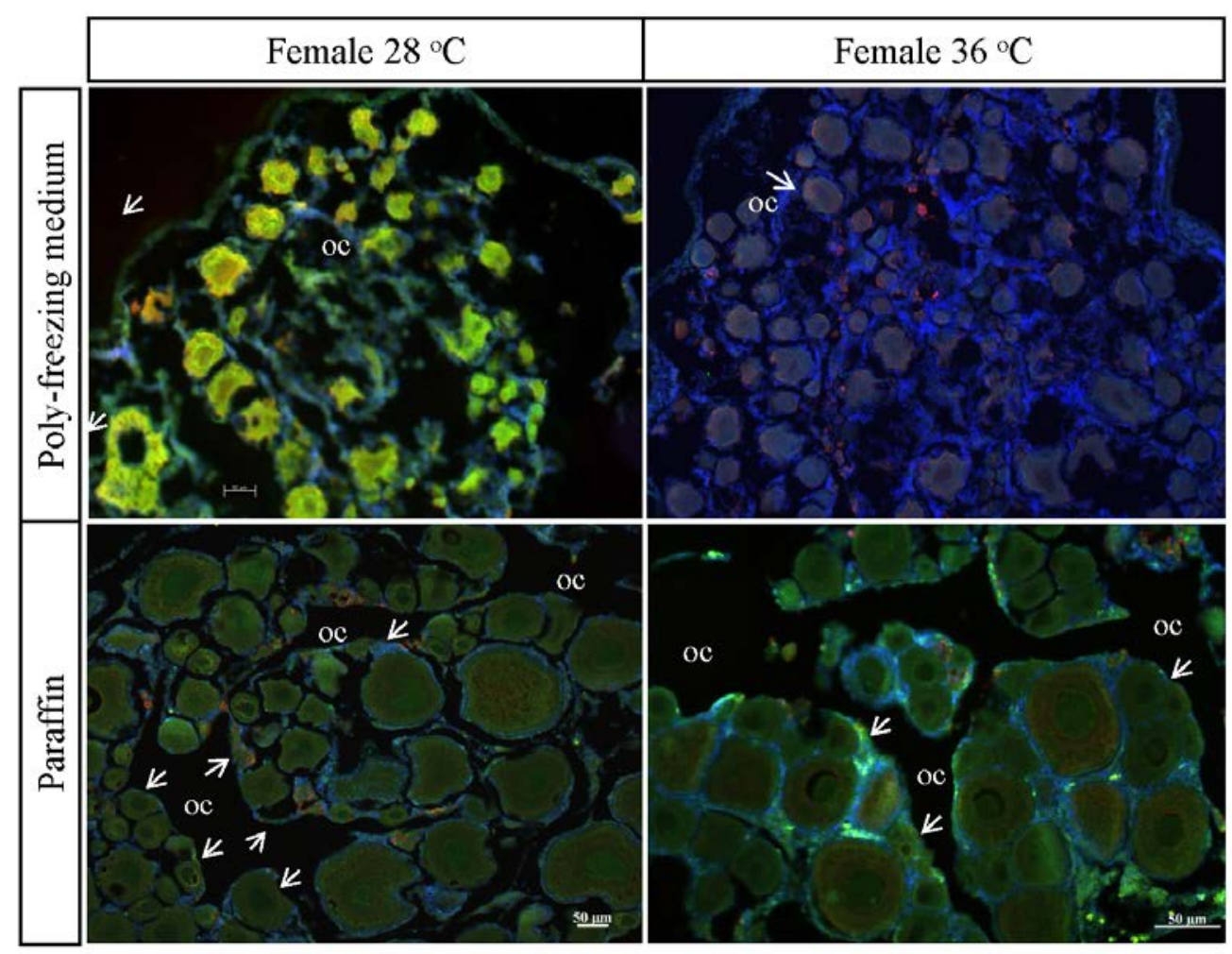

Figure 7. Vasa-PCNA immunostaining reveals ovarian lamellae in paraffin-sections as opposed to polyfreeze-tissue-freezing-medium sections in 120 day old tilapia females from control or temperature treatment group. (arrows = ovarian lamella; OC = ovarian cavity; scale bars $=50 \mu \mathrm{m}$ for all pictures). 


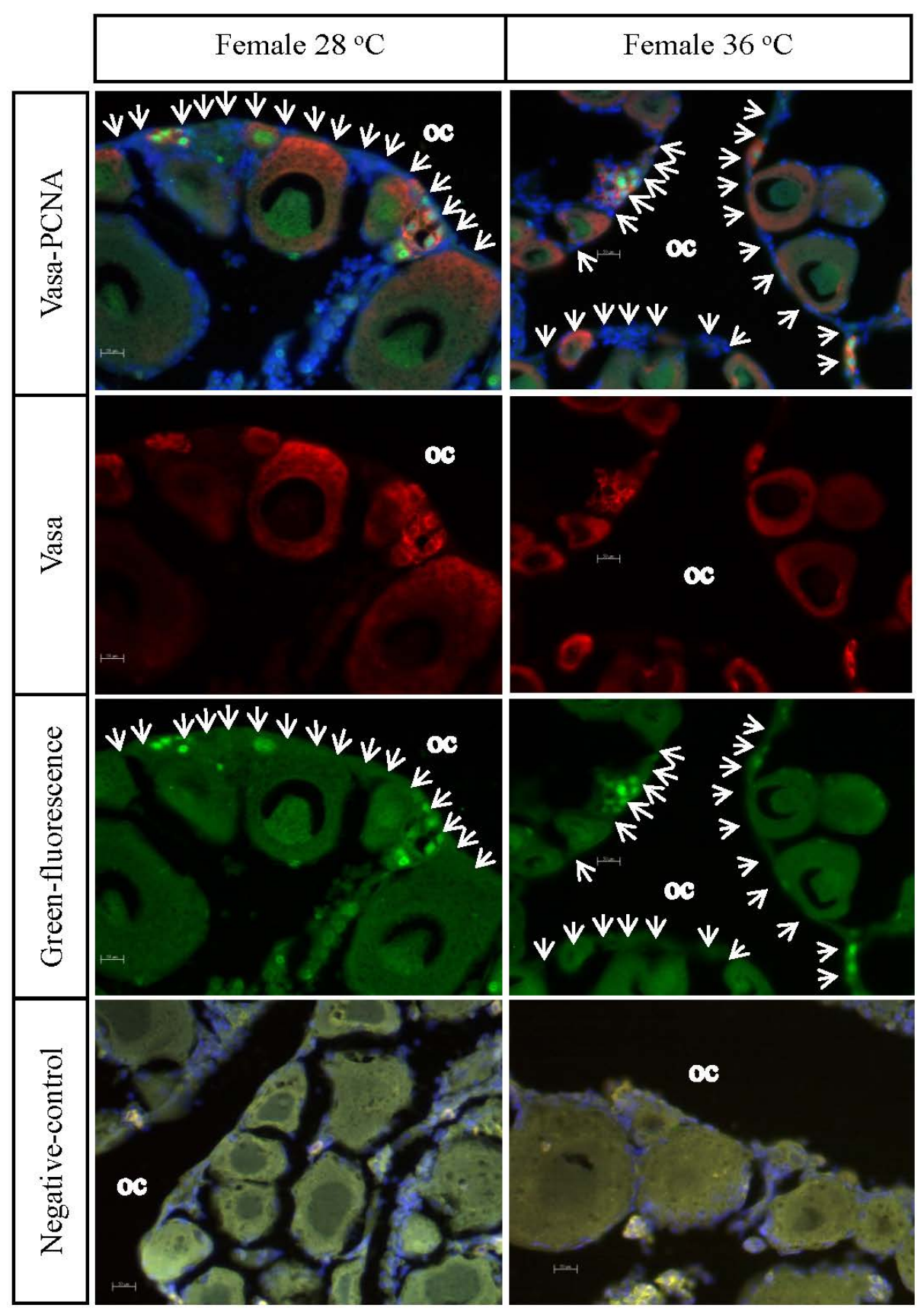

Figure 8. Vasa-PCNA immunostaining of ovary cross sections in control and temperaturetreated female Nile tilapia at 90 dpf displays germline stem cells at the germinal epithelium of the ovigerous lamellae. (Vasa-positive staining = red; PCNA-positive staining = green; arrows $=$ germinal epithelium of the ovigerous lamellae; $\mathrm{OC}=$ ovarian cavity; DAPI stained DNA blue; scale bars $=50 \mu \mathrm{m}$ for all pictures). 


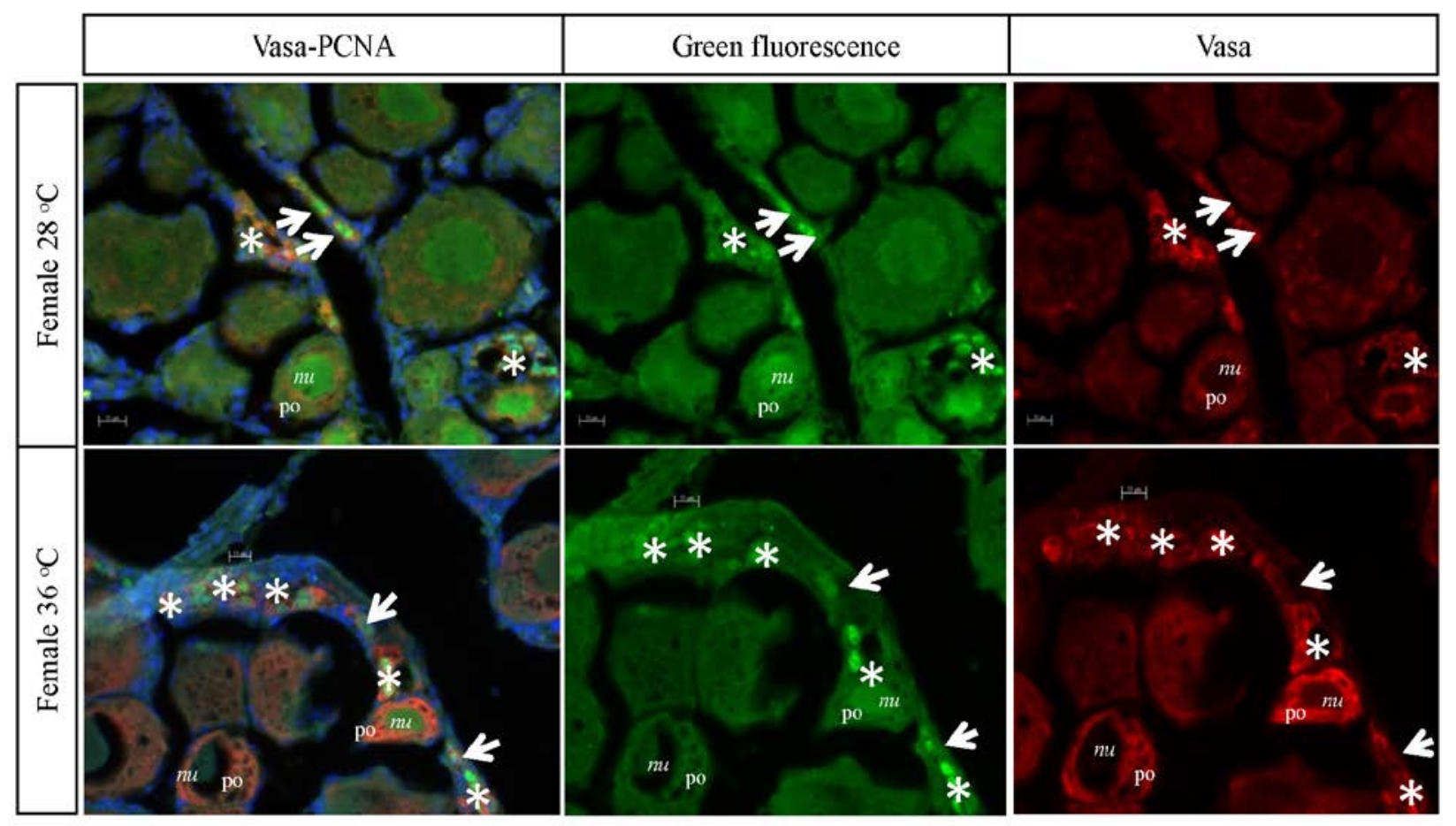

Figure 9. Vasa-PCNA immunostaining of female ovary cross sections in control and temperature-treated Nile tilapia at $90 \mathrm{dpf}$ reveals single (arrows) and nest-like clutches (asterisks) of ovarian germline stem cells. Ovaries display primary growth phase oocytes (po) and germline stem cells. (DAPI stained DNA blue; red = vasa-positive staining; green = PCNA-positive staining; nu = nucleus; scale bars $=50 \mu \mathrm{m}$ for control females; scale bars $=10 \mu \mathrm{m}$ for treatment group).

At age above 90 dpf a tendency for decreased germline stem cell numbers in the germinal epithelium of the ovary was observed. Although differences could not be quantified, the decrease in germline stem cell numbers occurred to equal extent in the control and treatment group. Nevertheless, at advanced age both nested germline stem cell clutches and single isolated germ cells were detected around the germinal epithelium of the ovigerous lamellae without discernible differences between treatment groups (Figure 10). Whereas, PCNA signals were comparable for 60, 120, 180 and 210 day old fish, at age 90 dpf, ovaries possessed distinct and strong PCNA immunostaining in germline stem cells irrespective of treatment (Figure 11). Moreover, differences in PCNA signal strength 
between single isolated germinal stem cells and the nest-like clutches were observed. Single isolated germinal stem cells expressed strong signals whereas, amongst cells within nest-like structures, both strong and weak vasa-PCNA signals were detected. Overall, the comparison of ovaries derived from temperature-treated and control females revealed only subtle, if any, difference in immunostaining.

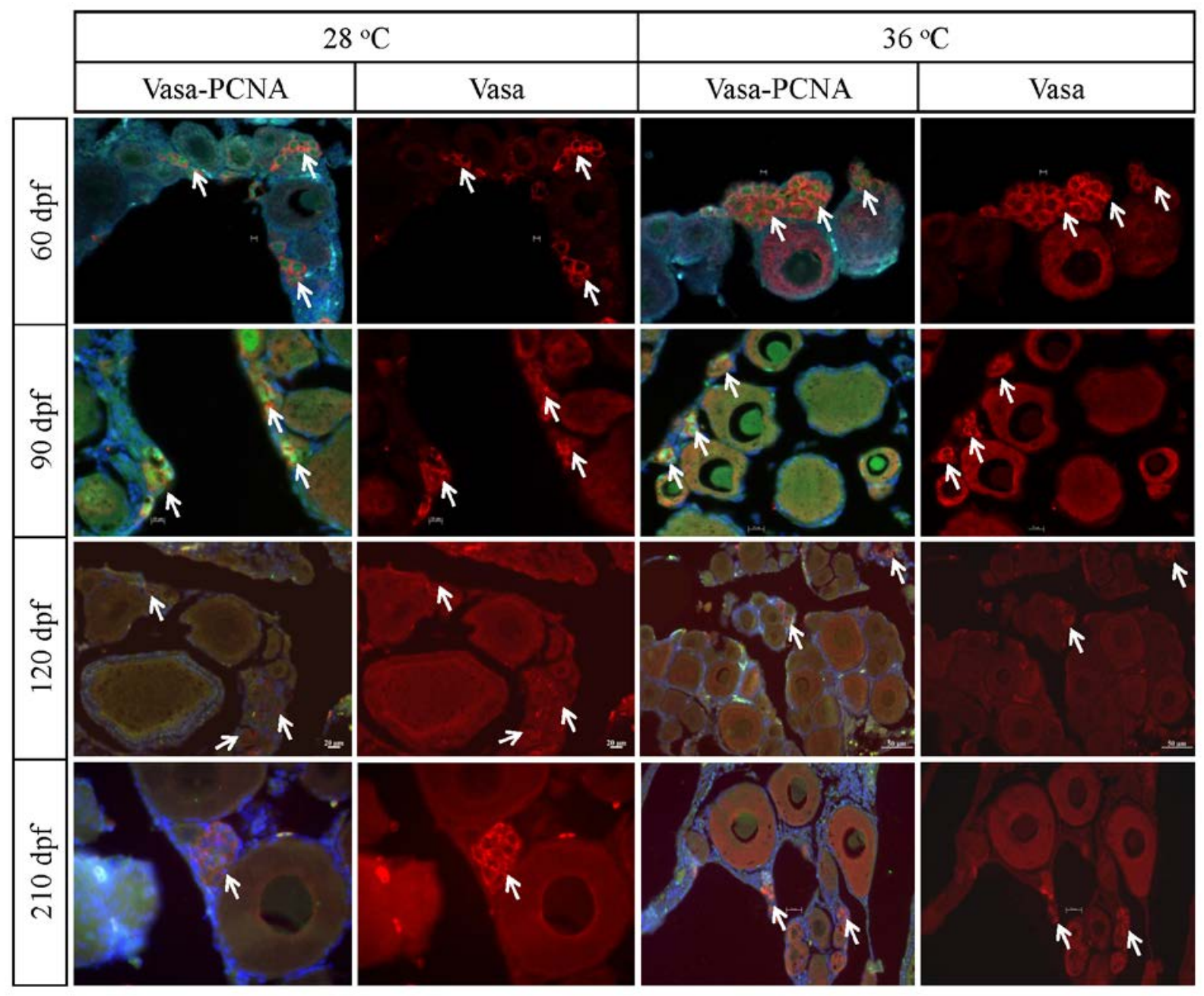

Figure 10. Development of ovarian germline stem cells from juvenile (60 dpf) to adulthood (210 dpf) in control and temperature-treated Nile tilapia females. Germline stem cells (arrows) were identified by Vasa (red) -PCNA (green) immunostaining. DAPI stained DNA blue. (Scale bars $=20 \mu \mathrm{m}$ for $60 \mathrm{dpf}$; scale bars $=10 \mu \mathrm{m}$ for $90 \mathrm{dpf}$; scale bars $=20 \mu \mathrm{m}$ for $120 \mathrm{dpf}$; scale bars $=13 \mu \mathrm{m}$ for $210 \mathrm{dpf}$ tilapia from control group; scale bars $=50 \mu \mathrm{m}$ for $210 \mathrm{dpf}$ tilapia from treatment group). 


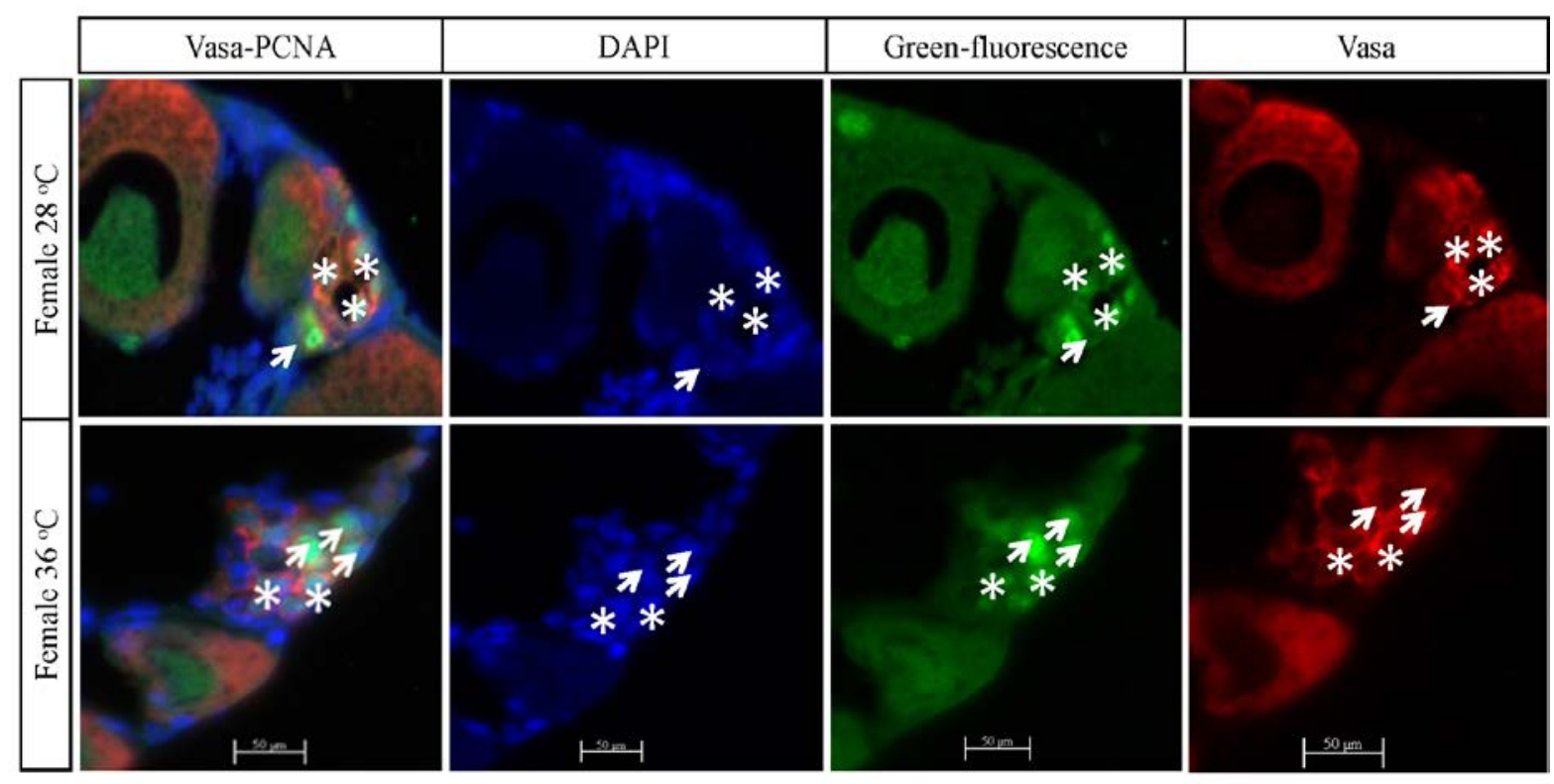

Figure 11. Strong- and faint Vasa-PCNA expressing cells revealed by immunostaining of female ovary cross sections in control and temperature-treated Nile tilapia at $90 \mathrm{dpf}$. (arrows $=$ strong expressing cells; asterisks = vasa-PCNA faint-expressing cells; DAPI stained DNA blue; Scale bars $=50 \mu \mathrm{m}$ for all pictures). 


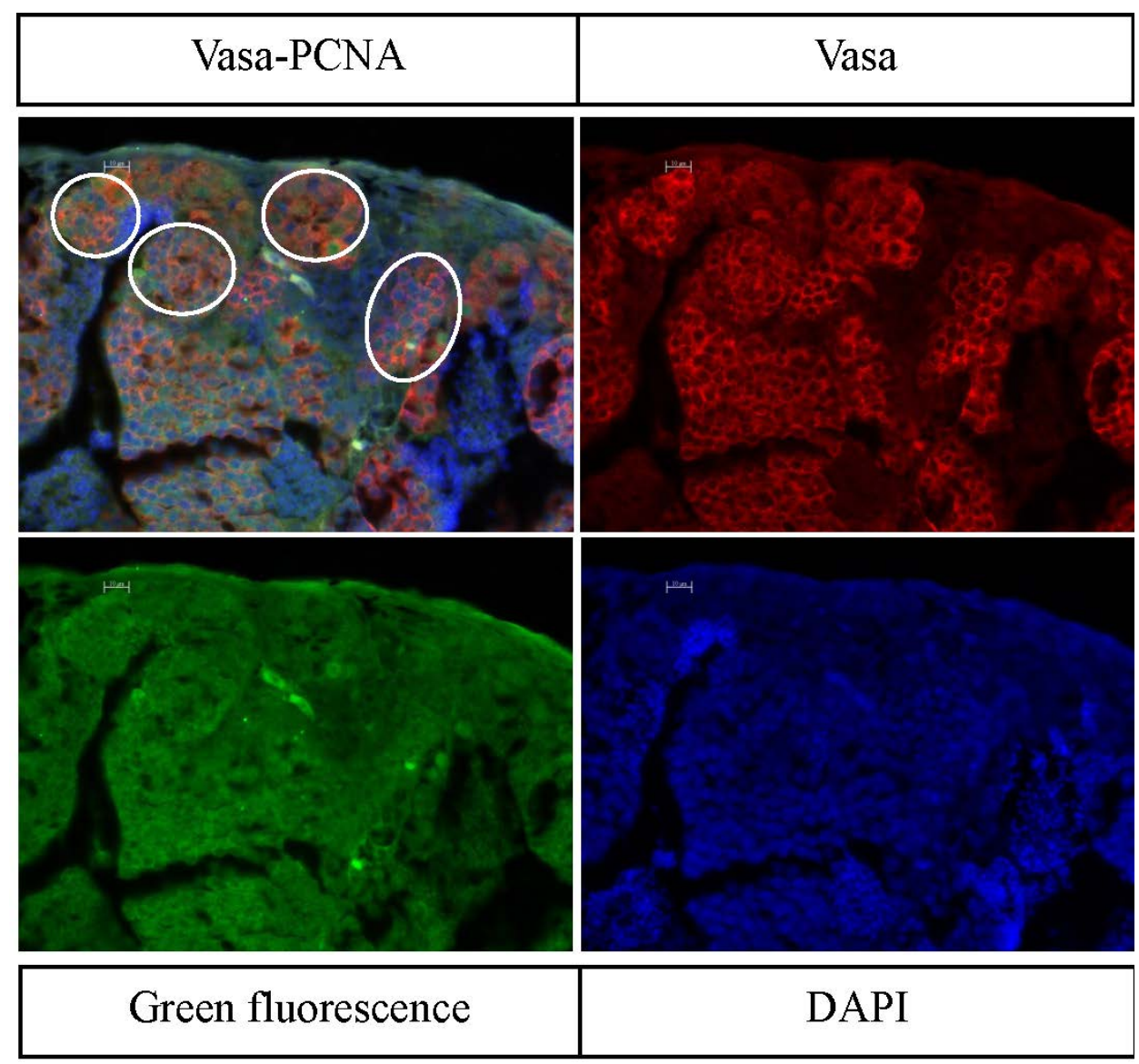

Figure 12. Testicular structure of temperature-induced pseudomale Nile tilapia at age 60 dpf, 120 dpf, and 210 dpf. Germline stem cells were identified by Vasa (red) - PCNA (green) immunostaining. (DAPI stains DNA blue; circles = lobules of the testes; scale bars $=20 \mu \mathrm{m}$ for $60 \mathrm{dpf}$ and $120 \mathrm{dpf}$; scale bars $=50 \mu \mathrm{m}$ for $210 \mathrm{dpf}$ ).

Apart from ovaries, testes from temperature-induced pseudomales were investigated. All temperature-induced pseudomales showed normal testicular tissue displaying germline stem cells (Figure 12). These were located in the testicular germinal epithelium. Immunostaining using Vasa and PCNA showed that mitotically active cells were located in epithelial tissue of testes. Large numbers of germ cells expressing Vasa and PCNA were further detected in the lobules of testes.

Lobules, like the germinal epithelium of the ovigerous lamellae in females, are typically containing germ cells. Immunostaining revealed that in temperature-treated pseudomales showed no depletion of germ cells had occurred. Testes of temperature-treated 
pseudomales consistently exhibited Vasa and PCNA positive immunostaining from 120 to 210 dpf. Only at 60 dpf no PCNA signal was detected in Vasa expressing germ line cells, indicating reduced mitotic activity of the germ line at that stage.

\subsection{Discussion}

Elevated temperature of $36^{\circ} \mathrm{C}$ at 10 to $20 \mathrm{dpf}$ is known to induce masculinization in temperature-responsive individuals of Nile tilapia [Baroiller et al., 1995; Tessema et al., 2006]. However, the mechanism determining the temperature-dependent sex in this species is only partially understood. The amh gene as well as a QTL on LG20 play a role in temperature-dependent sex reversal [Wessels et al., 2014; Palaiokostas et al., 2015]. Moreover, germ cells show increased vulnerability towards elevated temperatures during early developmental stages, as observed, for example, in the pufferfish [Lee et al., 2009]. Furthermore, the presence of germ cells determines the sexual fate at least in the protogynous zebrafish and the pufferfish [Siegfried and Nüsslein-Volhard, 2008] and it can lead to altered gonadal development [Uchida et al., 2004; Ito et al., 2008]. The effect high temperature applied in the course of temperature-dependent sex reversal exerts on germ cells in Nile tilapia remains unknown so far. Further, little is known about the effect of temperature treatments on subsequent gonadal development in non-masculinized females and its implications for adaptive significance of temperature-dependent sex reversal. Therefore, the aim of the present study was the analysis of ovaries derived from temperature-treated but non-sex-reversed XX-individuals.

Results clearly indicate that the temperature treatment applied during the critical phase of sex differentiation from 10-20 dpf leads to normal ovaries in the females and normal testes in the $37 \%$ temperature-induced pseudomales. Intersex structures in the gonads were not observed. Ovaries of temperature-treated XX tilapia individuals showed no abnormalities or deviation from normally developed germline stem cells. The immuno-histological 
analysis provides evidence for the identification of germline stem cells in ovarian tissue of control and temperature-treated individuals. In the present study, both, temperature-treated as well as control females showed germline stem cells, based upon positive PCNA-Vasa and DNA staining. Furthermore, also temperature-induced pseudomales exhibited germline stem cells, most likely spermatogonial stem cells. The resulting male gonads exhibited a consistent testis structure. Lee et al. [2009] observed masculinization of female somatic gonad tissue after germ cell depletion in high temperature-treated pufferfish. The present study did not reveal such rigorous changes. Here, female to male sex reversal was not a result of complete germ cell depletion of the gonad. However, a speculative hypothesis might be that in the present experiment a threshold number of germ cells was reached (low number of PGCs), sufficient to induce pseudomale differentiation of gonads, but allowing some germ cells to survive and develop normal testes. Confirmation of this hypothesis would require the comparison of temperature-induced XX pseudomales and normal XY males regarding the presence and quantity of germinal stem cells, which the present study is lacking.

In contrast to female mammals which have only a finite number of germ cells, teleost germ cells exhibit the life-long ability to multiply [Hanna, and Hennebold, 2014]. On the male side, teleosts show similar characteristics as mammals, featuring germline stem cells. Grier [2000]) described germline stem cells in common snook and also in rainbow trout [Grier et al., 2007].

In the latter they identified the germinal epithelium in spent females and found that it contained oogonia, mitotic oogonia, early diplotene oocytes, and pre-follicle cells sheathed within nests. Grier et al. [2007] stated that the germinal epithelium is a source of germline stem cells both in male and female individuals. In the present study, germline stem cells were only identified in the germinal epithelium. Moreover, there were no obvious differences between temperature-treatment group and control group, based on 
immunostaining. As conclusion, the temperature treatment applied during the sensitive window from 10-20 dpf induced a complete female to male sex-reversal in a certain proportion of the population. In females not affected by the temperature treatment development of the ovary and function of germ line cells remained largely unaffected. Immunostaining of ovarian tissue in Nile tilapia indicated that germline stem cells were localized in the germinal epithelium of the ovigerous lamellae. Moreover, two types of ovarian germline stem cells were identified; single isolated germline stem cells as well as nest-like clusters of germline stem cells, resembling germinal cradle-like structures. [Nakamura, 2010]] first described the "germinal cradle” as a germline stem cell supporting structure in medaka. Germline stem cells need a micro-environment or niche supported by somatic cells for their existence [Spradling et al., 2011]. This micro-environment provides essential factors for cell identity, proliferation, and survival. Further, Wildner et al. [2013] investigated early germ cells in ovaries of Ostariophysians fish: Pimelodus maculatus and Serrasalmus maculates, identifying two kinds of oogonia, single oogonia and proliferating oogonia that build nests.

Spradling et al. [2011] stated that the mechanisms of germline stem cell renewal are probably conserved amongst species. They assumed that stem cell renewal occurs to balance the number of daughter cells and induce stem cells. Likewise, in the present study germline stem cells were observed at all developmental stages, indicating a continuous renewal and proliferation.

In summary, germline stem cells were identified in the germinal epithelium of ovigerous lamellae in control and temperature-treated genetically female Nile tilapia at age 90 to 210 dpf. Immunostaining, using PCNA and Vasa, revealed the presence of both single isolated germline as well as nest-like clutches of germline stem cells, the latter resembling the germinal cradle of the ovarian cord. Furthermore, between females that had not responded to temperature treatment and untreated control females no differences were found with 
regard to proportions of germ line stem cells or immune staining. It may thus be assumed that in non-responding females the production of gametes and, thus, maintenance of reproductive fitness, had remained unimpaired; an assumption that needs to be confirmed by appropriate fertilization trials. Moreover, the lack of susceptibility to a temperature challenge conceivably plays an evolutionary role for adaptive significance of temperaturedependent sex reversal, as it could promote a balanced sex ratio. The germinal epithelium of sex-reversed pseudomales accommodated germ line stem cells as well as germ cells. Nonetheless, in tilapia it remains obscure whether apoptosis of oocyte- or germline stem cells is responsible for the temperature dependent change in phenotypic sex. Further studies are needed to analyse the effect of temperature treatment on germline stem cells and their relation to temperature-induced sex reversal and reproductive fitness.

\section{Acknowledgement}

We gratefully acknowledge Holger Knaut for generous gift of zebrafish-Vasa antibody and Berti Manshausen for technical assistance.

\subsection{References}

Alvarenga ER de, França LR de: Effects of different temperatures on testis structure and function, with emphasis on somatic cells, in sexually mature Nile Tilapias (Oreochromis niloticus). Biol Reprod 80:537-544 (2009).

Baroiller J-F, Chourrout D, Fostier A, Jalabert B: Temperature and sex chromosomes govern sex ratios of the mouth-brooding Cichlid fish (Oreochromis niloticus). J Exp Zool 273:216-223 (1995). 
Baroiller JF, D’Cotta H: Environment and sex determination in farmed fish, in: Comparative Biochemistry and Physiology - C Toxicology and Pharmacology (2001), pp 399-409.

Braat AK, Van De Water S, Goos H, Bogerd J, Zivkovic D: Vasa protein expression and localization in the zebrafish. Mech Dev 95:271-274 (2000).

D’Cotta H, Fostier A, Guiguen Y, Govoroun M, Baroiller JF: Aromatase plays a key role during normal and temperature- induced sex differentiation of Tilapia Oreochromis niloticus. Mol Reprod Dev 59:265-276 (2001).

Devlin RH, Nagahama Y: Sex determination and sex differentiation in fish: An overview of genetic, physiological, and environmental influences. Aquaculture 208:191-364 (2002).

Grier $\mathrm{H}$ : Ovarian germinal epithelium and folliculogenesis in the common snook, Centropomus undecimalis (Teleostei: Centropomidae). J Morphol 243:265-281 (2000).

Grier HJ, Uribe MC, Parenti LR: Germinal epithelium, folliculogenesis, and postovulatory follicles in ovaries of rainbow trout, Oncorhynchus mykiss (Walbaum, 1792) (Teleostei, Protacanthopterygii, Salmoniformes). J Morphol 268:293-310 (2007).

Gustafson EA, Wessel GM: Vasa genes: Emerging roles in the germ line and in multipotent cells. BioEssays 32:626-637 (2010).

Hanna CB, Hennebold JD: Ovarian germline stem cells: An unlimited source of oocytes? Fertil Steril 101:20-30 (2014). 
Hattori RS, Gould RJ, Fujioka T, Saito T, Kurita J, Strüssmann CA, et al.: Temperaturedependent sex determination in Hd-rR medaka Oryzias latipes: Gender sensitivity, thermal threshold, critical period, and dmrt1 expression profile. Sex Dev 1:138-146 (2007).

Hayashi Y, Kobira H, Yamaguchi T, Shiraishi E, Yazawa T, Hirai T, et al.: High temperature causes masculinization of genetically female medaka by elevation of cortisol. Mol Reprod Dev 77:679-686 (2010).

Ito LS, Takahashi C, Yamashita M, Strüssmann CA: Warm Water Induces Apoptosis, Gonadal Degeneration, and Germ Cell Loss in subadult Pejerrey Odontesthes bonariensis (Pisces, Atheriniformes). Physiol Biochem Zool 81:762-774 (2008).

Kelman Z: PCNA : structure, functions and interactions Oncogene 14: 629-640 (1997).

Knaut H, Pelegri F, Bohmann K, Schwarz H, Nuesslein-Volhard C: Zebrafish vasa RNA but not its protein is a component of the germ plasm and segregates asymmetrically before germline specification. J Cell Biol 149:875-888 (2000).

Knaut H, Steinbeisser H, Schwarz H, Nuesslein-Volhard C: An evolutionary conserved region in the vasa $3^{\prime}$ UTR targets RNA translation to the germ cells in the zebrafish. Curr Biol 12:454-466 (2002).

Kobayashi T, Ishibashi R, Yamamoto S, Otani S, Ueno K, Murata O: Gonadal morphogenesis and sex differentiation in cultured chub mackerel, Scomber japonicus. Aquac Res 42:230-239 (2011).

Kobayashi T, Kajiura-Kobayashi H, Nagahama Y: Differential expression of vasa homologue gene in the germ cells during oogenesis and spermatogenesis in a teleost fish, tilapia, Oreochromis niloticus. Mech Dev 99:139-142 (2000). 
Kobayashi Y, Nagahama Y, Nakamura M: Diversity and plasticity of sex determination and differentiation in fishes. Sex Dev 7:115-125 (2012).

Lee KH, Yamaguchi A, Rashid H, Kadomura K, Yasumoto S, Matsuyama M: Germ cell degeneration in high-temperature treated pufferfish, Takifugu rubripes. Sex Dev 3:225-232 (2009).

Nagasawa K, Fernandes JMO, Yoshizaki G, Miwa M, Babiak I: Identification and migration of primordial germ cells in Atlantic salmon, Salmo salar: Characterization of Vasa, Dead End, and Lymphocyte antigen 75 genes. Mol Reprod Dev 80:118-131 (2013).

Nakamura M, Bhandari RK, Higa M: The role estrogens play in sex differentiation and sex changes of fish. Fish Physiol Biochem 28:113-117 (2003).

Nakamura M, Kobayashi T, Chang XT, Nagahama Y: Gonadal sex differentiation in teleost fish. J Exp Zool 281:362-372 (1998).

Nakamura M, Takahashi H: Sex differentiation in Tilapia mossambica, with special regard to the time of estrogen treatment effective in inducing complete feminization of genetic males [Internet]. Bull Fac Fish Hokkaido Univ 24:1-13 (1973).

Nakamura S, Kobayashi K, Nishimura T, Tanaka M: Ovarian germline stem cells in the teleost fish, medaka (Oryzias latipes). Int J Biol Sci 7:403-409 (2011).

Nakamura S: Identification of Germline Stem Cells 1561 (2010).

Okutsu T, Suzuki K, Takeuchi Y, Takeuchi T, Yoshizaki G: Testicular germ cells can colonize sexually undifferentiated embryonic gonad and produce functional eggs in fish. Proc Natl Acad Sci USA 103:2725-2729 (2006). 
Olsen LC, Aasland R, Fjose A: A vasa-like gene in zebrafish identifies putative primordial germ cells. Mech Dev 66:95-105 (1997).

Palaiokostas C, Bekaert M, Khan MGQ, Taggart JB, Gharbi K, McAndrew BJ, et al.: A novel sex-determining QTL in Nile tilapia (Oreochromis niloticus). BMC Genomics 16:171 (2015).

Pfennig F, Kurth T, Meissner S, Standke A, Hoppe M, Zieschang F, et al.: The social status of the male Nile tilapia (Oreochromis niloticus) influences testis structure and gene expression. Reproduction 143:71-84 (2012).

Raz E: Primordial germ-cell development: the zebrafish perspective. Nat Rev Genet 4:690-700 (2003).

Saito D, Morinaga C, Aoki Y, Nakamura S, Mitani H, Furutani-Seiki M, et al.: Proliferation of germ cells during gonadal sex differentiation in medaka: Insights from germ cell-depleted mutant zenzai. Dev Biol 310:280-290 (2007).

Selim KM, Shinomiya A, Otake H, Hamaguchi S, Sakaizumi M: Effects of high temperature on sex differentiation and germ cell population in medaka, Oryzias latipes. Aquaculture 289:340-349 (2009).

Sengoku T, Nureki O, Nakamura A, Kobayashi S, Yokoyama S: Structural Basis for RNA Unwinding by the DEAD-Box Protein Drosophila Vasa. Cell 125:287-300 (2006).

Siegfried KR, Nuesslein-Vollhardt C: Germ line control of female sex determination in zebrafish. Dev Biol 324:277-287 (2008).

Slanchev K: Molecular mechanisms governing germ line development in zebrafish and the role of this lineage in sexual differentiation [Internet]. Dev Biol (2005). Available from: http://webdoc.sub.gwdg.de/diss/2006/slanchev/ 
Spradling A, Fuller MT, Braun RE, Yoshida S: Germline stem cells. Cold Spring Harb Perspect Biol 3:a002642 (2011).

Strome S, Updike D: Specifying and protecting germ cell fate. Nat Rev Mol Cell Biol 16:406-16 (2015).

Tessema M, Müller-Belecke A, Hörstgen-Schwark G: Effect of rearing temperatures on the sex ratios of Oreochromis niloticus populations. Aquaculture 258:270-277 (2006).

Uchida D, Yamashita M, Kitano T, Iguchi T: An aromatase inhibitor or high water temperature induce oocyte apoptosis and depletion of P450 aromatase activity in the gonads of genetic female zebrafish during sex-reversal. Comp Biochem Physiol - A Mol Integr Physiol 137:11-20 (2004).

Wessels S, Sharifi RA, Luehmann LM, Rueangsri S, Krause I, et al.: Allelic variant in the anti-muellerian hormone gene leads to autosomal and temperature-dependent sex reversal in a selected Nile tilapia line. PLoS One 9 (2014).

Wildner DD, Grier H, Quagio-Grassiotto I: Female germ cell renewal during the annual reproductive cycle in Ostariophysians fish. Theriogenology 79:709-724 (2013).

Wong T-T, Saito T, Crodian J, Collodi P: Zebrafish germline chimeras produced by transplantation of ovarian germ cells into sterile host larvae. Biol Reprod 84:11901197 (2011).

Xu H, Lim M, Dwarakanath M, Hong Y: Vasa identifies germ cells and critical stages of oogenesis in the asian seabass. Int J Biol Sci 10:225-235 (2014).

Yoshizaki G, Ichikawa M, Hayashi M, Iwasaki Y, Miwa M, Shikina S, et al.: Sexual plasticity of ovarian germ cells in rainbow trout. Development 137:1227-30 (2010). 
Yoshizaki G, Takeuchi Y, Kobayashi T, Ihara S, Takeuchi T: Primordial germ cells: The blueprint for a piscine life. Fish Physiol Biochem 26:3-12 (2002).

Yoshizaki G, Takeuchi Y, Sakatani S, Takeuchi T: Germ cell-specific expression of green fluorescent protein in transgenic rainbow trout under control of the rainbow trout vasa-like gene promoter. Int J Dev Biol 44:323-326 (2000). 
CHAPTER 4

GENERAL DISCUSSION 


\subsection{Sex ratio, somatic growth and GSI}

Tilapias are among the most important aquaculture species group world-wide. They have great potential for poverty alleviation and are simultaneously considered a world market commodity. Frozen fillets are exported to markets in the US, Europe, or Asia. A mainstay of more than $50 \%$ of seafood coming from aquaculture is represented by tilapia. Although tilapia can thrive under poor conditions and on diets that contain low proportions of fish meal [Cressey, 2013], one of the major constraints for sustainability, i.e. hormonal sexreversal, is yet to be overcome. Application of temperature in order to gain a higher male proportion is considered as an environmental friendly alternative approach. The frequent use of hormones to induce the phenotypic sex in sexually undifferentiated fry is considered to harm the environment as well as human beings if necessary protective clothes are not available. The present study reports the effect of elevated temperature on the phenotypic sex in genetically female populations and consequences for female ovarian development and fate of germline stem cells.

In the present study elevated temperature of $36^{\circ} \mathrm{C}$ from 10 to $20 \mathrm{dpf}$ was applied to induce masculinization of genetically female (XX) individuals. The genetically all-female population was derived from crosses between normal females and a temperature-sex reversed male from a line selected for high temperature-responsiveness ( $>90 \%$ males after $36^{\circ} \mathrm{C}$ treatment from 10 to $20 \mathrm{dpf}$ ) [Wessels and Hoerstgen-Schwark, 2007, 2011]. In the present study a male percentage of $37 \%$ was found in the temperature-treatment group. In contrast no males were observed in the control group. This result is in accordance with Tessema et al. [2006] and Baroiller et al. [1995] who reported that elevated temperature (> $34{ }^{\circ} \mathrm{C}$ ) affects masculinization rate. Wessels and Hoerstgen-Schwark [2011] reported sex ratios of $93 \%$ and $50 \%$ after a three-generation selection experiment for high and low temperature sensitivity, respectively. In contrast to the present study the authors used 
mixed sex families (XX/XY). Therefore the male ratios in the present study, which used temperature-induced pseudomales as sires, were significantly lower. However, treatment of mixed-sex populations likely results in higher male ratios, as about $50 \%$ of observed males are genetic males (XY). Depending on temperature-responsiveness of the dam and sire a share of up to about $50 \%$ of the remaining XX-individuals will be masculinized, thus leading to sex ratios of up to $100 \%$ males. Distinct male ratios are frequently observed, as sex ratio in Nile tilapia populations is affected by several factors. Sex determination in Nile tilapia involves major and minor genetic as well as exogenous factors such as temperature. Wessels and Hoerstgen-Schwark [2007, 2011] reported that the temperatureresponsiveness differs amongst families in Nile tilapia and is a heritable trait. Recent studies using genetic markers revealed that genetic markers on LG 1, LG20 and 23 contribute to sex determination [Palaiokostas et al., 2013; Palaiokostas et al., 2015; Gammerdinger et al., 2014; Wessels et al., 2014]. At least the QTL on LG20 and LG23 are involved in temperature-dependent sex reversal [Palaiokostas et al., 2015; Wessels et al., 2014; Lühmann et al., 2012].

In the present study, a tendency for better growth performance in the temperature-treated females was found. The body mass and body length of temperature-treated females were higher in the temperature-treatment group compared to the control. Generally in poikilothermic fish environmental temperature is known to affect somatic growth [Pauly, 1980]. Furthermore, an age- and temperature-related pattern was found for the GSI. In contrast to the body mass and body length, which were higher in the temperature-treatment group, the GSI of the control was slightly higher in the control group at an age above 180 dpf $(\mathrm{P}>0.05)$. Although the differences between control group and temperature-treated group were generally subtle for GSI, the oocyte development showed a distinct pattern among the experimental groups. 
Energy allocation for reproduction was shown to compromise growth in fish [Jennings, and Philipp, 1992]. Therefore, although subtle, the negative relationship between growth performance and GSI, as observed in the present study, might be a consequence of higher energy allocation for reproduction in controls compared to temperature-treated individuals. However, the experimental design of the present study is not sufficiently robust to draw this conclusion. Moreover, the reason for a reduced GSI in temperature-treated fish remains unknown. One road of enquiry should be the effect of temperature treatments applied during sex differentiation on the fertility and fecundity of temperature-treated Nile tilapia females, as compared to control females. Temperature-treated tilapia pseudomales are known to be fertile [Tessema et al., 2006; Baroiller et al., 2009; Wessels et al., 2014]. However, the effect of temperature-treatments on the sperm quality, regarding density, motility and fertilization rate is scarce [Senior et al., 2016]. They assumed that overall there is little evidence for large systematic differences between sperm quality of pseudoand wild-type males. More research is needed to investigate the effect of high-temperature treatments applied during the critical phase of sex differentiation on fecundity in females, too.

\subsection{The influence of temperature treatments on ovarian development in Nile} tilapia (O. niloticus)

Macro-morphological observations of the ovaries showed immature stage at $90 \mathrm{dpf}$ both in temperature-treatment and control group. Ovarian maturation commenced at $120 \mathrm{dpf}$ in both groups with slight differences. There were six fish in every sampling point time. Thus, might be caused an erratic pattern. Nevertheless, the sequence of events is clearly discernible.

The oocyte composition of immature and mature ovaries differs. Immature ovaries possessed only oocytes of the primary growth stage, whereas mature ovaries were 
composed of all oocyte stages i.e. primary growth, cortical alveolus, vitellogenic, and mature oocytes. By 90 dpf ovaries were still in an immature state. At 120 dpf ovaries had entered the maturation stage.

Oogenesis is known as the transformation of oogonia to oocytes [Wallace, and Selman, 1981]. Subsequently oocyte development can be categorized into the following stages, as described in Fundulus heteroclitus: Chromatin nucleolus stage, perinucleolus stage, cortical alveolus stage, vitellogenic stage and oocyte maturation stage [Wallace, and Selman, 1981]. Whereas the chromatin nucleolus and the perinucleolus phase still belong to the primary growth phase, with follicle diameters ranging from 8 to $175 \mu \mathrm{m}$, diameters quickly rise to 175 to $550 \mu \mathrm{m}$ at the cortical alveolus stage. Subsequently, the follicles enter vitellogenesis and gain in size rapidly, ranging from $0.55 \mathrm{~mm}$ to $1.35 \mathrm{~mm}$. Finally, mature oocytes can reach sizes of $1.35 \mathrm{~mm}$ and more.

At $90 \mathrm{dpf}$, the only prevalent stages were the chromatin nucleolus and perinucleolus stage, indicating that the ovary in both the control and the temperature-treated group had entered the primary growth phase. Generally, with increasing age, fewer cells in the primary growth phase could be observed due a relative shift in the ovary towards advanced developmental stages (cortical alveoli, vitellogenic, mature oocyte). Cortical alveoli were discernable at age 120 dpf. A higher proportion of vitellogenic oocytes were found in control females when compared to temperature-treated females at 150 and $180 \mathrm{dpf}$ (P < 0.05). The vitellogenic stage indicates oocyte growth, as it involves the inclusion of vitellogenin, produced by the liver, into oocytes [Wallace and Selman, 1990]. Following the vitellogenic stage, mature oocytes provide the eggs for spawning. In control females at ages above $150 \mathrm{dpf}$ more mature oocytes were than in temperature-treated females.

Investigation of the cytological course of events led to the conclusion that, on the basis of the available material, it appears unlikely that the temperature treatment exerted a significant effect on gonadal function in non-masculinized female tilapia. Temperature 
treatment caused enhanced somatic growth. There was a non-significant tendency for the GSI in the non-masculinized temperature-treated females to be lower than in the control females. Implications for the fitness of temperature-treated females should be elucidated in future studies.

\subsection{The effect of temperature treatments on ovarian germline stem cells in Nile tilapia (O. niloticus)}

Increased temperature treatments $\left(>34{ }^{\circ} \mathrm{C}\right)$ applied during the critical phase of sex differentiation can lead to masculinization in Nile tilapia [Baroiller et al., 2009]. Yet, the underlying principles of temperature-dependent sex determination remain poorly understood. QTL on LG20 as well as the amh gene seem to be involved in orchestration of temperature-dependent sex reversal [Palaiokostas et al., 2015; Wessels et al., 2014]. Germ cells are known to be highly susceptible for high temperatures at precocious age, as determined in the pufferfish [Lee et al., 2009]. In the protogynous zebrafish as well as the pufferfish germ cells play an important role during sex determination [Siegfried, and Nüsslein-Volhard, 2008]. High temperatures can also result in altered gonadal development [Uchida et al., 2004; Ito et al., 2008]. In the present study immunostaining was used for the identification of germline stem cells in ovaries of control and temperature-treated female Nile tilapia. Evidence is provided by PCNA- and vasa-positive staining that temperature-treated as well as control females possess germline stem cells. So do the pseudomales in the temperature-treatment group in their testes. Lee et al. [2009] reported masculinization of the somatic ovarian tissue when pufferfish were exposed to elevated temperature. However, in the present the number of germ line stem cells in temperature-treated pseudomales was not quantified. To test the hypothesis that gonads lacking germline stem cells and germ cells or showing reduced numbers of those will turn 
male has to be proven through a thorough comparison of temperature-treated pseudomales and normal males.

In mammals, females dispose only of a terminate number of germ cells. Teleosts, instead, can multiply germ cells throughout their lifetime [Hanna, and Hennebold, 2014]. Grier [2000] reported germline stem cells in the common snook, and similarly in rainbow trout [Grier et al., 2007]. The authors state that germline stem cells originate from the germinal epithelium, both in male and female individuals. In the present study, they were located exclusively in the germinal epithelium. Regarding the presence and numbers of germline stem cells, the present study did not reveal differences between temperature-treatment group and control group, based on immunostaining. The germline stem cells were identified in the germinal epithelium of the ovigerous lamellae. The ovarian germline stem cells could further be subdivided into single isolated germline stem cells and nest-like clusters of germline stem cells. These nest-like structures resemble the germinal cradles first describe by Nakamura et al., [2010] as structures supporting germline stem cells in medaka. In Drosophila germline stem cells require a micro-environment or niches supported by somatic cells [Spradling et al., 2011]. This micro-environment deals with crucial supporting factors for cell identity, proliferation, and survival. It may be surmised that this does also apply to fish [Spradling et al., 2011]. The authors further outlined that stem cell renewal balances the number of daughter cells and induction of stem cells.

In accord with the findings of Nakamura [2010] in medaka, in the present study were was evidence for the presence of germline stem cells at all developmental stages, indicating a continuous renewal and proliferation of germline stem cells also in Nile tilapia.

In temperature-induced pseudomales, germline stem cells were identified in the germinal epithelium of testes. Immunostaining of vasa and PCNA revealed mitotically active cells both in the epithelium and in the lobules of the testes. Similar to the germinal epithelium of the ovigerous lamellae in females, lobules are structures within testes containing germ 
cells. Pfennig et al. [2012] used immunostaining with PCNA antibodies to identify mitotically active germ cells in normal XY Nile tilapia males. They described PCNA expression in spermatogonial cysts and the Sertoli cells surrounding these cysts.

\subsection{Conclusions}

In the present study, elevated temperature treatment from $10 \mathrm{dpf}$ to $20 \mathrm{dpf}$ leads to masculinization in $37 \%$ of genetic female individuals. In untreated control the masculinizations were not occurred. Comparison of ovarian development in control and non-masculinized temperature-treated females revealed a slight difference in ovarian development.

Germline stem cells were identified through vasa-PCNA immunostaining in Nile tilapia females and males. Vasa-PCNA-expressing cells as germline stem cells were located in the germinal epithelium of ovaries. Germline stem cells were observed at all sampled ages, with slightly declining trend in number at advanced ages. Prominent differences between the temperature treatment group and control group were not discernable.

\subsection{References}

Baroiller J-F, Chourrout D, Fostier A, Jalabert B: Temperature and sex chromosomes govern sex ratios of the mouthbrooding Cichlid fish (Oreochromis niloticus). J Exp Zool 273:216-223 (1995).

Baroiller JF, D’Cotta H, Bezault E, Wessels S, Hoerstgen-Schwark G: Tilapia sex determination: Where temperature and genetics meet. Comp Biochem Physiol - A Mol Integr Physiol 153:30-38 (2009).

Cressey, D (n.d.) Tilapia standard showcases continuing growth of aquaculture: Nature News Blog. 2013. Available: http://blogs.nature.com/news/2012/08/tilapiastandard-showcases-continuing-growth-of-aquaculture.html. Accessed 2013 July 10. 
Gammerdinger WJ, Conte M a, Acquah E a, Roberts RB, Kocher TD: Structure and decay of a proto-Y region in Tilapia, Oreochromis niloticus. BMC Genomics 15:975 (2014).

Grier $\mathrm{H}$ : Ovarian germinal epithelium and folliculogenesis in the common snook, Centropomus undecimalis (Teleostei: Centropomidae). J Morphol 243:265-281 (2000).

Grier HJ, Uribe MC, Parenti LR: Germinal epithelium, folliculogenesis, and postovulatory follicles in ovaries of rainbow trout, Oncorhynchus mykiss (Walbaum, 1792) (Teleostei, Protacanthopterygii, Salmoniformes). J Morphol 268:293-310 (2007).

Hanna CB, Hennebold JD: Ovarian germline stem cells: An unlimited source of oocytes? Fertil Steril 101:20-30 (2014).

Ito LS, Takahashi C, Yamashita M, StrÃ $1 / 4$ ssmann CA: Warm Water Induces Apoptosis, Gonadal Degeneration, and Germ Cell Loss in Subadult Pejerrey Odontesthes bonariensis (Pisces, Atheriniformes). Physiol Biochem Zool 81:762-774 (2008).

Jennings MJ, Philipp DP: Reproductive investment and somatic growth rates in longear sunfish. Environ Biol Fishes 35:257-271 (1992).

Lee KH, Yamaguchi A, Rashid H, Kadomura K, Yasumoto S, Matsuyama M: Germ cell degeneration in high-temperature treated pufferfish, Takifugu rubripes. Sex Dev 3:225-232 (2009).

Lühmann LM, Knorr C, Hörstgen-Schwark G, Wessels S: First evidence for familyspecific QTL for temperature-dependent sex reversal in Nile tilapia (Oreochromis niloticus). Sex Dev 6:247-256 (2012).

Nakamura S, Kobayashi K, Nishimura T, Higashijima S -i., Tanaka M: Identification of Germline Stem Cells in the Ovary of the Teleost Medaka. Science (80- ) 328:15611563 (2010).

Nakamura S: Identification of Germline Stem Cells 1561 (2010). DOI: 10.1126/science.1185473 
Palaiokostas C, Bekaert M, Khan MGQ, Taggart JB, Gharbi K, McAndrew BJ, et al.: A novel sex-determining QTL in Nile tilapia (Oreochromis niloticus). BMC Genomics 16:171 (2015).

Palaiokostas C, Bekaert M, Khan MGQ, Taggart JB, Gharbi K, McAndrew BJ, et al.: Mapping and Validation of the Major Sex-Determining Region in Nile Tilapia (Oreochromis niloticus L.) Using RAD Sequencing. PLoS One 8:1-9 (2013).

Pauly D: On the Interrelationships between Natural Mortality, Growth Parameters, and Mean Environmental Temparature in 175 Fish Stocks. J du Cons 39:175-192 (1980).

Pfennig F, Kurth T, Meissner S, Standke A, Hoppe M, Zieschang F, et al.: The social status of the male Nile tilapia (Oreochromis niloticus) influences testis structure and gene expression. Reproduction 143:71-84 (2012).

Senior AM, Lim JN, Adolfsson S, Dunja K, Nakagawa S: Condition and reproductive investment in the western mosquitofish ( Gambusia affinis ): little evidence for condition-dependent sex-biased investment (2016).

Siegfried KR, Nüsslein-Volhard C: Germ line control of female sex determination in zebrafish. Dev Biol 324:277-287 (2008).

Spradling A, Fuller MT, Braun RE, Yoshida S: Germline stem cells. Cold Spring Harb Perspect Biol 3:a002642 (2011).

Tessema M, Müller-Belecke A, Hörstgen-Schwark G: Effect of rearing temperatures on the sex ratios of Oreochromis niloticus populations. Aquaculture 258:270-277 (2006).

Uchida D, Yamashita M, Kitano T, Iguchi T: An aromatase inhibitor or high water temperature induce oocyte apoptosis and depletion of P450 aromatase activity in the gonads of genetic female zebrafish during sex-reversal. Comp Biochem Physiol - A Mol Integr Physiol 137:11-20 (2004).

Wallace R a, Selman K: Ultrastructural aspects of oogenesis and oocyte growth in fish and amphibians. J Electron Microsc Tech 16:175-201 (1990). 
Wallace RA, Selman K: Cellular and dynamic aspects of Oocyte growth in Teleosts. Integr Comp Biol 21:325-343 (1981).

Wessels S, Hoerstgen-Schwark G: Selection experiments to increase the proportion of males in Nile tilapia (Oreochromis niloticus) by means of temperature treatment. Aquaculture 272:S80-S87 (2007).

Wessels S, Hoerstgen-Schwark G: Temperature dependent sex ratios in selected lines and crosses with a YY-male in Nile tilapia (Oreochromis niloticus). Aquaculture 318:79-84 (2011).

Wessels S, Sharifi RA, Luehmann LM, Rueangsri S, Krause I, Pach S, et al.: Allelic variant in the anti-müllerian hormone gene leads to autosomal and temperaturedependent sex reversal in a selected nile tilapia line. PLoS One 9 (2014). DOI: 10.1371/journal.pone.0104795 


\section{Curriculum vitae}

Aulidya Nurul Habibah

Personal Detail

Date of birth $\quad$ November $25^{\text {th }}, 1985$

Place of birth Banyumas, Indonesia

Nationality Indonesian

Work experience

04/11/2013-15/11/2013 Immunohistochemistry works at The Institute of Zoology, Technische Universität Dresden, Germany

2013-2015 Laboratory works at the Institute of Anatomy and Cell Biology, University Medical School Goettingen, Germany

Contribution of conference

17/09/2014 - 19/09/2014 Tropentag 2014, Prague, Czech Republic.

\section{Education}

6/09-3/11 Master of Science Faculty of Biology, University of Jenderal Soedirman, Indonesia

6/04-5/09 Bachelor of Science Faculty of Biology, University of Jenderal Soedirman, Indonesia 


\section{Acknowledgement}

Alhamdulillah, all praises be to Allah, The Al Mighty The Most Merciful.

My deep gratitude to Prof. Dr. Hoerstgen-Schwark for accepting me as her PhD student and for being of great assistance at all times.

I would like to express my deepest acknowledgement to Prof. Wolfgang Holtz for great supervision during my research and writing.

My great thank to Prof. Joerg Wilting for allowed me working at The Institute of Anatomy and Cell Biology, University Medical School Goettingen

My great thank to Prof. Juergen Hummel for willingness to be my third examiner.

My special thanks to Dr. Stephan Wessels for great assistance and discussion during research and thesis writing.

My special thank also to Dr. Frank Pfennig for kindness teaching of immunohistochemistry at The Institute of Zoology, Technische Universität Dresden and for all family, Antonia, Grit, and Konstantin who were very kind during my stay in Dresden.

I owe thank to Dr. Ahmad Reza Sharifi for statistical analyses.

My great thank to Berti Manshausen for excellent assistances during histological works. And to all people of the histology laboratory: Christina, Sonja, Dr. Kerstin Buttler and Dr. Juergen Becker, my kind regards for their kindnesses and helps.

My deep appreciations to aquaculture team division for taking care of tilapias during my research: Birgit Rheinelt, Tharwat Attalah, Hannah Mruck, and Jacob Gaehrken.

My sincerer thank to Indonesian community of Goettingen for kindness during my stay in Goettingen, especially to Dr. Condro Wibowo.

Lovely thank to Ibu, for unconditional love, praying, and motivations for my successfulness. And also thank to my sisters and brother for always supporting me.

And my greatest thank to Indonesian government and DAAD for the scholarship. 